\title{
The Management and Organizational Practices Survey (MOPS): Cognitive Testing*
}

\author{
by
}

\author{
Catherine Buffington \\ U.S. Census Bureau
}

\author{
Kenny Herrell \\ U.S. Census Bureau
}

Scott Ohlmacher

U.S. Census Bureau \& University of Maryland

CES 16-53 November, 2016

The research program of the Center for Economic Studies (CES) produces a wide range of economic analyses to improve the statistical programs of the U.S. Census Bureau. Many of these analyses take the form of CES research papers. The papers have not undergone the review accorded Census Bureau publications and no endorsement should be inferred. Any opinions and conclusions expressed herein are those of the author(s) and do not necessarily represent the views of the U.S. Census Bureau. All results have been reviewed to ensure that no confidential information is disclosed. Republication in whole or part must be cleared with the authors.

To obtain information about the series, see www.census.gov/ces or contact J. David Brown, Editor, Discussion Papers, U.S. Census Bureau, Center for Economic Studies 5K034A, 4600 Silver Hill Road, Washington, DC 20233, CES.Papers.List@census.gov. To subscribe to the series, please click here. 


\begin{abstract}
All Census Bureau surveys must meet quality standards before they can be sent to the public for data collection. This paper outlines the pretesting process that was used to ensure that the Management and Organizational Practices Survey (MOPS) met those standards. The MOPS is the first large survey of management practices at U.S. manufacturing establishments. The first wave of the MOPS, issued for reference year 2010, was subject to internal expert review and two rounds of cognitive interviews. The results of this pretesting were used to make significant changes to the MOPS instrument and ensure that quality data was collected. The second wave of the MOPS, featuring new questions on data in decision making (DDD) and uncertainty and issued for reference year 2015, was subject to two rounds of cognitive interviews and a round of usability testing. This paper illustrates the effort undertaken by the Census Bureau to ensure that all surveys released into the field are of high quality and provides insight into how respondents interpret the MOPS questionnaire for those looking to utilize the MOPS data.
\end{abstract}

\footnotetext{
* Any opinions and conclusions expressed herein are those of the authors and do not necessarily represent the views of the U.S. Census Bureau. All results have been reviewed to ensure that no confidential information is disclosed. The MOPS was developed as a partnership between the Census Bureau and an external research team that includes Nick Bloom (Stanford), Erik Brynjolfsson (MIT), and John Van Reenen (MIT). The work of this team for MOPS2010 was supported by a grant from the National Science Foundation (NSF) and through administrative support from the National Bureau of Economic Research (NBER). The work for MOPS2015 was supported by grants from NSF, NBER, the Kauffman Foundation, and the Sloan Foundation. We thank Lucia Foster, Ron Jarmin, and Julius Smith for helpful comments and review of this paper.
} 


\section{Introduction}

The U.S. Census Bureau uses quality standards to guide all stages of data collection. One such quality standard requires that each data collection instrument must be tested and refined to ensure that the instrument can be understood and answered and does not cause undue burden for the respondents. ${ }^{1}$ One method of pre-testing a survey instrument is via cognitive interviews. Cognitive interviews are used to understand the respondents' thought processes as they work through the instrument and to use that knowledge to improve the survey questions. (Pick and Brennan; 2015a, b) These thought processes include comprehension of the question, retrieval of the relevant information, and mapping the information to the provided responses. When working with business surveys, information retrieval often relies on gathering data from administrative records or other members of the business, and cognitive interviews can be used to evaluate how respondents will gather data to complete the instrument.

The Management and Organizational Practices Survey (MOPS) was developed through a partnership between the U.S. Census Bureau and external researchers from Stanford University and Massachusetts Institute of Technology (MIT). The first wave of the MOPS was fielded as a supplement to the 2010 Annual Survey of Manufacturers (ASM). A second MOPS survey wave was conducted for 2015 with input from the same research team plus additional team members from the University of Chicago and the University of Toronto. For a more general overview of the development and content of the MOPS, see Buffington, Foster, Jarmin, and Ohlmacher (2016). Both the 2010 and 2015 MOPS instruments were tested and refined based on the results of cognitive interviews. Copies of the final MOPS 2010 and MOPS 2015 instruments can be found in the appendices of Buffington, Foster, Jarmin, and Ohlmacher (2016).

This paper provides a brief overview of the cognitive testing process and subsequent refinement of the survey instruments for both the MOPS 2010 and the MOPS 2015. Section 2 discusses the MOPS 2010; Section 3 covers the MOPS 2015; and Section 4 concludes.

\section{MOPS 2010}

The MOPS is a joint project between the Census Bureau and an external research team including Nick Bloom (Stanford), Erik Brynjolfsson (MIT), and John Van Reenen (MIT). Bloom and Van Reenen proposed questions related to management practices for the original MOPS instrument. These questions were based on their experiences developing and conducting the first cross-country survey of firm management practices, the World Management Survey (WMS). Brynjolfsson helped develop content for the MOPS related to organizational practices and the

\footnotetext{
${ }^{1}$ For more information on the Census Bureau's quality standards, see http://www.census.gov/about/policies/quality/standards.html
} 
adoption of data-driven decision making. The MOPS was subject to internal Census Bureau expert review, two rounds of pretesting interviews, and a round of usability testing.

\subsection{Expert Review}

The expert review of the MOPS was conducted by the Census Bureau (Response Improvement Research Staff (RIRS) in the Office of Economic Planning and Innovation) early in the development of the MOPS instrument. Gerver and Thomas (2009) wrote a report on the expert review of the MOPS instrument that includes both general and question-specific recommendations, which are summarized in this subsection. Many of the standardized aspects of the MOPS instrument were introduced in response to the recommendations of this expert review, including:

- Formatting each item as a direct question,

- Explicitly stating that estimates are acceptable in numerical response questions,

- Referring to the sample period in each question,

- Placing negative responses and responses that generate a skip pattern at the end of response lists, and

- Grouping like questions together.

Placing the responses that generate a skip pattern at the end of response lists encourages respondents to read to the end of the list and limits the degree to which respondents might answer inaccurately to complete the survey more quickly.

The expert review also suggested considering the "social desirability bias" inherent in certain questions. According to Gerver and Thomas (2009), "Social desirability bias is the tendency for respondents to reply in a manner that is viewed as more favorable.” For example, question one asks "what best describes what happened at this establishment when a problem in the production process arose” with possible responses "We fixed it but did not take further action"; "We fixed it and took action to makes sure that it did not happen again"; "We fixed it and took action to make sure that it did not happen again, and had a continuous improvement process to anticipate problems like these in advance"; and "No action was taken." The expert review identified the third option as being most favorable, with the fourth option being clearly undesirable. No changes were made to the instrument for this particular question, however.

Question two asks "how many key performance indicators were monitored at this establishment?" At the time of the expert review, there were three possible responses: "1-2 production performance indicators"; "3 or more production performance indicators"; and "None." The expert review suggested that " 3 or more..." was clearly most socially desirable of these options. In response, the granularity of responses was increased to include "3-9 key performance indicators" and "10 or more key performance indicators.” This provides an option for respondents who monitor more than two indicators but who do not feel that monitoring a great number of indicators would be warranted. This change was believed to address the issue of 
social desirability bias since it may not be appropriate for some businesses to track 10 or more key performance indicators. As such, this response is not clearly more desirable than other options, although respondents may still identify the null response as undesirable.

Initially, question six, which asks respondents "what best describes the time frame of production targets at [their] establishment," had four options: "No production targets"; "Main focus short term (less than one year) production targets"; "Main focus long term (more than three years) production targets"; and "Balanced focus on both short term and long term production targets." The expert review suggested that using the phrase "balanced focus” made that response socially desirable. Thus, the language was altered to read "Combination of short-term and longterm production targets.”

The expert review also recommended removing the recall component of each question to reduce respondent burden, but since examining changes in management practices within establishments over time was a key goal of the MOPS, this recommendation was not incorporated into the instrument. Recommendations from the expert review that were not used immediately to update the survey instrument were subsequently evaluated in light of further evidence from pretesting interviews with prospective respondents. Table 1 includes all recommendations from the expert review by question number from the final MOPS 2010 instrument.

\subsection{Cognitive Interviews}

Two rounds of cognitive interviews were conducted to further review the MOPS 2010 instrument. The first round covered 9 respondents in the San Jose, CA metropolitan area and 5 respondents in the Chicago, IL area, while the second round consisted of 8 interviews in the San Francisco, CA area and 5 interviews in the Philadelphia, PA area. Lucia Foster from the Census Bureau's Center for Economic Studies (CES) and members of the research team observed a subsample of these interviews. Locations for the cognitive interviews were chosen based on the concentration of manufacturing in metro areas, mix of manufacturing industries in metro areas, availability of sponsor(s) to observe the cognitive interviews, and budgetary concerns.

The MOPS is somewhat unique among Census surveys, in that instruments for establishments of multi-unit firms are mailed to the plant address from the Business Register (BR) for the attention of the "plant manager." " Most Census surveys are sent to the business address, usually headquarters, for distribution among the plants. Because the sample frame for the cognitive interviews was the Annual Survey of Manufacturing (ASM), cognitive interviews were generally held at that headquarters or an administrative unit for multi-unit firms.

Kristin Stettler of RIRS produced internal Census Bureau documentation of the cognitive testing process, which is summarized in this subsection. Stettler (2011) states, “The goals of the

\footnotetext{
${ }^{2}$ Forms that are returned as “undeliverable as addressed” are re-mailed to the administrative unit address.
} 
cognitive interviewing were to determine whether respondents understood and answered the draft questionnaire in a manner that meets the questionnaire's intent, identify likely respondents and data retrieval strategies, and identify any other related reporting issues or concerns.” The documentation by Stettler (2011) is not as formal as later cognitive testing documentation, largely due to time constraints when the MOPS 2010 survey instrument was developed. Some changes to the instrument were made based on oral reports, and written documentation is not available for some changes and recommendations. Table 2 reflects the known recommendations from cognitive testing of the MOPS 2010.

While some respondents stated that they would be unable to provide recall data, generally respondents felt that they could reasonably provide the data based on either their own experiences or information from a co-worker. In order to clarify that respondents could provide estimates and thereby limit respondent burden, the following language was included on the letter that accompanied the MOPS 2010 instrument in the mail: "Estimates are acceptable when responding to questions on this report form."

Although some respondents exhibited signs of social desirability bias in response to certain questions during the cognitive interviews, the response options were not changed since the evidence for social desirability bias was inconclusive. In particular, some evidence of social desirability bias was expressed with respect to questions 13 and 14 . These questions ask respondents about the primary bases for promotion of non-managers and managers, respectively, at the establishment. Two of the responses for each of these questions include the option that promotions are based at least in part on "other factors (for example, tenure or family connections)." Some respondents expressed that they recognized that promoting based on family connections was undesirable. Because the social desirability bias was not consistently displayed among respondents, those items were not substantially altered. Evidence from the results of the MOPS 2010 indicates that establishments did select responses that could be considered less socially desirable than other options.

The definition of "manager," clearly a key concept for this survey, was clarified based on the results of cognitive testing. In earlier drafts of the MOPS, a manager was defined as "someone who is involved in pay and promotions for employees who work for them.” However, interviewees indicated that many managers do not necessarily have a say in pay and promotions, particularly where union influence is strong. This definition was extended to "someone who has employees reporting directly to them, with whom they meet on a regular basis, and whose pay and promotion they may be involved with." Additionally, in response to the finding from the cognitive testing that unionization plays an important role in the determination of management questions at the establishment, a question was added to the MOPS after the first round of testing asking respondents, "what percent of all employees at the establishment were members of a labor union?” 
Question 10 (12) asks "when production targets were met, what percentage of non-managers (managers) at this establishment received performance bonuses?” During cognitive interviews, respondents expressed confusion about the term "performance," noting that "it was not clear whether 'performance' referred to individual performance or to plant/company performance.” (Stettler, 2011) The draft of the MOPS instrument that was used during testing followed the aforementioned questions with a question asking "what were non-managers' performance bonuses usually based on?" with responses including "Their own performance as measured by production targets," "Their team or shift performance as measured by production targets," "Their establishment's performance as measured by production targets,” and “Their company's performance as measured by production targets.” This question, with some slight language modifications and the addition of a response for "No performance bonuses," was moved to appear immediately proceeding the question on what share of non-managers received bonuses in order to clarify that "performance” could refer to performance of the business on several levels. A version of the question asking about the basis of bonuses for managers was also added immediately proceeding the question on what share of managers received performance bonuses.

Question 7, which asks "how easy or difficult [it was for the] establishment to achieve its production targets," originally had responses such as "Somewhat easy (we hit our targets 90\% to 99\% of the time)," "Neither easy nor difficult (we hit our targets 50\% to 89\% of the time)," and "Somewhat difficult (we hit our targets $10 \%$ to $49 \%$ of the time)." Participants in the cognitive interviews noted that they could set targets that were not "somewhat easy" but still achieve 9099\% of those targets. Thus, the responses were changed to a scale that could more easily be translated to a Likert scale, with the "normal" effort exerted by workers at the firm serving as a baseline. The new responses include "Possible to achieve with some effort," "Possible to achieve with normal amount of effort," and "Possible to achieve with more than normal effort."

Other changes made in response to cognitive interview observations include adding the word "production" to the question "who prioritized or allocated tasks to production workers at this establishment" and using boldfaced font for the phrase "Mark all that apply" for each of the five questions having that instruction. ${ }^{3}$ The former change addressed confusion expressed by participants in cognitive interviews, while the latter change differentiates questions where respondents are encouraged to mark all that apply from the rest of the checkbox survey questions which specify that respondents should "Check one box for each year."

Not all suggested changes were implemented. For example, question 1 requires respondents to "Check one box for each year" in response to the question "what happened ... when a problem in the production process arose?" Participants in the cognitive interviews noted that production problems are not always met with the same response. Similarly, question 5 asks where "production display boards showing output and other key performance indicators" were located

\footnotetext{
${ }^{3}$ Questions 3, 4, 9, 11, and 29 on the MOPS 2010 instrument.
} 
at the establishment. Respondents noted that it was possible to use alternative means to disseminate information without having display boards.

It should be noted that questions 27 and 28 on the MOPS 2010, which ask about the availability and use of data to support decision making, were written and added to the instrument after the completion of cognitive testing. These two questions were based on existing research by Brynjolfsson on the use of data in decision making and were added because they were believed to be complementary to the other organizational questions on the MOPS 2010. The questions were based on a survey of senior human resource managers at approximately 330 large, publicly traded firms conducted in 2008 by Brynjolfsson, Hitt, and Kim (2011) in conjunction with McKinsey \& Company. These questions were later tested as part of the cognitive testing process for the 2015 MOPS, where they are questions 24 and 25, respectively.

\subsection{Usability Testing}

The goal of usability testing is to examine potential issues that a respondent may have when using an electronic instrument; often, there is often validation of any changes made to the instrument after earlier rounds. Because the respondent works through the entire electronic survey instrument during the usability testing, it also allows for cognitive testing that takes into consideration the survey instrument as a whole, rather than focusing on specific questions or sections.

Dave Tuttle of RIRS prepared a report on usability testing for the MOPS 2010. (Tuttle, 2011) He reports that no major problems were encountered during the usability testing phase, although respondents did not always notice instructions that read "select all that apply" for specific questions. Respondents also desired an opportunity to view or print a PDF of their responses when reviewing their responses. Table 3 lists all of the recommendations made as part of the usability testing for the MOPS 2010. Because the electronic instrument for the MOPS 2010 was deactivated after the survey collection ended, we cannot be certain whether or not all recommendations were accepted.

\section{MOPS 2015}

The new questions added to the MOPS 2015 instrument were also subject to two rounds of cognitive testing, as well as usability testing for the electronic instrument. ${ }^{4}$ The new questions on the MOPS 2015 are concentrated in two sections: "Data in Decision Making” (Section C) and "Uncertainty" (Section D). Section C consists of four new questions and the two questions on this subject that were added to the MOPS 2010 after cognitive interviews were complete. As a result, the full section was tested as part of the cognitive testing process for MOPS 2015. Section

\footnotetext{
${ }^{4}$ Unlike the MOPS 2010, the MOPS 2015 did not undergo formal expert review due to time constraints and the fact that most of the content had already undergone this review for 2010. Although the formal expert review was not conducted, the cognitive testing staff provided expert feedback throughout the testing process.
} 
D consists of eight new questions. There were also four new questions added to the "Background Characteristics" section of the instrument.

The new questions in Section C were developed in partnership with Brynjolfsson and Kristina McElheran (University of Toronto), who are experts on the use of data and technology in decision making. The new questions in Section D were developed in partnership with Bloom and Steven Davis (University of Chicago), who developed a similar survey with the Federal Reserve Bank of Atlanta. For more information on the development of content for the MOPS 2015, see Buffington, Foster, Jarmin, and Ohlmacher (2016). .

\subsection{Cognitive Interviews}

The first round of cognitive interviews took place in June 2015 in the Washington, DC, Detroit, MI, and Houston, TX metropolitan areas, and the second round took place in September and October 2015 in the San Francisco, CA and Boston, MA metropolitan areas. The first round of interviews "was exploratory in nature and the second round was confirmatory." (Pick and Brennan; 2015a, b) That is, the first round was used to collect information and make changes to the survey instrument. The second round was used to validate those changes to the survey instrument. A total of 32 establishments participated in cognitive testing; 3 in Washington, 8 in Detroit, and 7 each in Houston, San Francisco, and Boston. These participants were drawn from 13 different industries (as measured by 3-digit NAICS codes) and included both single- and multi-unit establishments.

As in 2010, the interviews were conducted in person at each establishment, with interviews taking approximately 45 minutes to complete. Testing was completed by the Census Bureau (Data Collection Methodology and Research Branch (DCMRB) $)^{5}$ with Buffington or Ohlmacher from CES serving as observers. Members of the research team, including Nick Bloom (Stanford), Erik Brynjolfsson (MIT), and Kristina McElheran (University of Toronto), also each observed one or more testing visit.

Kenneth Pick and Michael Brennan from DCMRB produced internal Census Bureau documentation of the findings and recommendations from each round of cognitive testing. These findings and the actions taken to develop the MOPS are summarized in this subsection. Table 4 includes all recommendations from the two rounds of cognitive interviews conducted for the MOPS 2015.

Establishments for testing were selected from the 2014 ASM mail sample. Participants in both rounds of cognitive testing can be broadly grouped into two categories: establishments that are the sole physical location for their parent firm (single-unit) versus establishments that are part of a firm that has multiple physical locations (multi-unit). The single-unit establishments interviewed "were generally small businesses with family members in numerous positions in

\footnotetext{
${ }^{5}$ This is the same unit that did testing for MOPS 2010, under a new name.
} 
upper management,” and many performed custom work for their customers, making the generalization necessary to complete the MOPS questionnaire difficult for the respondents. (Pick and Brennan, 2015a)

In the first round of testing, the team visited mostly corporate headquarters locations when interviewing participants from multi-unit firms, while a deliberate effort to visit establishments other than headquarters was made in the second round of testing. As noted above, the MOPS is unique among Census surveys in that it is mailed to the establishment address rather than the firm's headquarters. The MOPS survey utilizes this strategy because the content of the MOPS is often specific to the plant-level operations and may best be answered by managers at the plants. By visiting both headquarters and plant locations of multi-unit firms, the cognitive testing team is able to better understand how respondents will react to completing the MOPS instrument. Plant-level addresses and respondent contact information for establishments of multi-unit firms were gathered from the "Certification" section of responses to the MOPS 2010 and used to prioritize the selection of cases from the 2014 ASM mail sample for cognitive testing in the second round of interviews.

Participants in the cognitive testing interviews generally held a position related to finance in their firm. Titles for the participants included CFO, plant controller, financial reporting manager, and financial analyst. In single-unit firms, these were often upper managers but were generally not upper management in multi-unit firms. The participants generally felt that they would be the primary respondents for the survey, but would coordinate with other members of the plant or firm as necessary. At single-unit establishments and at the headquarters of multi-unit firms, these respondents were the employees who complete the ASM forms, as well as other Census Bureau surveys. Respondents who had been in their position for five years or more generally had no difficulty with the recall questions, while those with shorter tenures would leave recall questions blank, leave the responses unchanged between 2010 and 2015, or consult with someone who might know the establishment's practices in 2010.

For the MOPS 2015, cognitive testing interviews focused primarily on questions which had not previously been tested as part of the MOPS 2010 testing process. In addition to the new questions, the two questions that were added after testing of the MOPS 2010 and the screener question for the “Organizational Practices” section, question 17, were retested.

As with the 2010 MOPS, many respondents had difficulty understanding question 17, "In 2010 and 2015, was the headquarters for this company at the same location as this establishment?” Respondents incorrectly interpreted this question as asking whether or not the firm had moved between 2010 and 2015, rather than asking about co-location between a plant and headquarters for a multi-unit firm. To address this issue, the language "In 2010 and 2015" was dropped in the MOPS 2015. 
As noted above, two questions on the use and availability of data to support decision making were written for the MOPS 2010 after the completion of cognitive testing, and as such were not subject to testing before their inclusion on the survey. Thus they were tested during the cognitive testing of the MOPS 2015. Participants frequently found these questions vague and were unsure about what kind of “data” should be considered. Since participants generally held financial positions in their firms, they frequently considered only financial forms of data. Pick and Brennan (2015a, b) suggest explicitly stating the type of data that interests the survey sponsors. Many respondents also had difficulty differentiating between the "availability" and the "use" of data, but some felt that the latter term referred to the establishment's "reliance" on data. The recommendations for change were not accepted in order to maintain consistency between the MOPS 2010 and MOPS 2015 instruments.

A similar issue with the term "data” affects the question 26 on the MOPS 2015, which asks "who chose what type of data to collect at this establishment." Prior to cognitive testing, the list of possible answers to this question included "Managers at other establishments including headquarters" which was modified based on respondent feedback to "Managers at headquarters and/or other establishments” to clarify that these directives may frequently come from headquarters rather than horizontally across the corporate structure.

The next question in this section asks respondents to "Consider each of the following sources of data and rate how frequently each source was used in decision making at this establishment." This question is followed by a question on how frequently each of three activities, "Design of new products or services," "Demand forecasting," and "Supply chain management” were influenced by data analysis and a question on how frequently the establishment uses predictive analytics. Pick and Brennan (2015a, b) suggest including an option between "monthly" and "yearly" and differentiating between "never" and "not applicable," which could not be done due to space constraints on the paper instrument.

The list of sources of data in question 27 was refined in a fashion similar to question 26 . Early drafts included sources such as "Production performance indicators and instruments," "Employee-specific performance indicators,” and "Employee input feedback.” These terms were not clear to respondents, but based on respondent feedback, these responses were replaced with the clearer options, "Performance indicators from production technology or instruments," "Formal or informal feedback from managers," and "Formal or informal feedback from production workers.”

The aforementioned questions on forecasting, including the questions on the frequency of data analysis in "design of new products or services" and "demand forecasting” and on the frequency of predictive analytics, were difficult for many respondents. This was true in particular for those at smaller firms that do not do much forecasting because they are a "job shop," where the plant makes custom goods to order according to client specifications rather than consistently 
producing a steady stream of identical goods. In these cases, the respondents were also unsure as to whether every job would constitute the design of a "new product or service."

Many participants in cognitive testing were tentative about providing forecasts in Section D "Uncertainty," likely due to their reluctance to be inexact on official forms, especially given that their roles frequently involved reporting official financial data. Unless the business had a formal forecasting group, most participants indicated that they were reluctant to forecast beyond the constraints of their available financial system. Some respondents indicated that they would only fill out one to three forecasts for 2017, were unclear about the meaning of the term "scenarios," or were unclear about the differences between the "High" and "Highest" scenarios or the "Low" and "Lowest" scenarios.

An example was added at the beginning of this section that sought to clarify the reporting of possible outcomes and their associated likelihoods, and text was added to stress that estimates were acceptable. The instructions and example for this section were developed during the confirmatory round of cognitive testing and were tested at a small number of establishments during that round, performing well. Additional validation of these instructions took place during electronic instrument usability testing.

New questions on background characteristics were also tested. Question 43 asks, "what percent of all employees at this establishment could be classified" as "part-time," "working flexible hours," working “from home one day or more per week," and "cross-trained.” Some respondents had difficulty classifying the workers at their firms as "working flexible hours" or being “cross-trained," but in general these terms were understood by respondents who utilize these practices. The list of employee classifications was refined based on respondent feedback, as was the list of possible responses for the subsequent question which asks whether the production of the establishment can best be described as "Job shop," "Batch production," "Cellular manufacturing," "Continuous flow (other than cellular manufacturing)," or "Research and development or prototyping.”

Question 45 originally asked whether or not the establishment was "owned by a family firm," but many cognitive interview participants were unclear about or misinterpreted the meaning of the term "family firm." The question was clarified to ask if the establishment is "owned 50\% or more by its founder(s) or member(s) of a founder's family?”

Similarly, question 46 originally asked if the establishment was "part of a multinational firm which has production establishments in other countries," but the term "multinational” was frequently misinterpreted by participants. Because changing the question to ask if the establishment was "part of a firm which has production establishments in other countries" is a more specific question without this confusing terminology, the word "multinational" was simply dropped from the question. 


\subsection{Usability Testing}

In addition to the two rounds of cognitive interviews the MOPS 2015 also underwent usability testing at ten establishments in the Los Angeles metro area and ten establishments in the New York City metro area in February 2016, spanning nine different 3-digit NAICS codes. Forty percent of interviews were conducted with establishments of multi-unit firms, while sixty percent of interviews involved respondents from single-unit firms. Each interview was scheduled to last for approximately one hour and was conducted by staff from the DCMRB. Buffington and Ohlmacher functioned as observers in New York and Los Angeles, respectively.

Usability testing focused on the functionality and appearance of the web instrument for the MOPS 2015. ${ }^{6}$ Respondents were asked to complete the full survey using the web instrument as if they were not being observed, but to verbalize any thoughts that they were having as they responded. The staff from the DCMRB who led the usability testing observed the actions and behaviors of respondents, paying particular attention to their ability to complete the survey successfully.

If respondents observed problems with the survey content or simply desired to discuss the content, they were encouraged to do so, although that was not the explicit purpose of the visits. As a result, the usability testing was able to provide insight in a manner similar to the cognitive interviews. A particular focus was placed on Section D, especially the example at the beginning of the section which was introduced after the second round of cognitive testing.

Herrell and Mesner (2016) produced documentation of the findings and recommendations from the usability testing. This subsection summarizes those findings and recommendations, as well as the actions taken to adjust the MOPS electronic instrument following the usability testing. Complete recommendations are listed in Table 5.

In general, respondents did not have major issues with usability of the web instrument. Most respondents found logging into the survey and navigating through the instrument to be straightforward. Many respondents stated that they would print a copy of the survey instrument to use as a worksheet before completing the survey online, and observed that the web instrument provided them that option. Similarly, respondents would generally print a PDF copy of their responses to save for their records after the survey was submitted. Some respondents in Los Angeles noted that they preferred to complete surveys online because they received instant verification that their responses had been successfully submitted after completing the survey.

Although the instrument tested well with respondents, some usability issues were identified and addressed to improve the web instrument before its release into the field. For example, on questions where respondents are instructed to select all that apply and "never" or "none" is

\footnotetext{
${ }^{6}$ See Buffington, Hennessy, and Ohlmacher (forthcoming) for more information on the collection and processing of the MOPS 2015, including internet collection.
} 
among the available options, the web instrument initially prohibited the selection of "never" or "none" with any other option. ${ }^{7}$ This was consistent with the web instrument for MOPS 2010. It was determined that selecting "none" or "never" does not necessarily contradict the selection of another option. Specifically, consider question 3, which asks "During 2010 and 2015, how frequently were key performance indicators reviewed by managers at this establishment?" It is conceivable that certain key performance indicators (KPIs) are reviewed "daily," while another KPI is collected but "never" reviewed.

Many participants reported that they were unsure if their data was being saved as they completed the survey. Because the default programming of Census web survey instruments is to have the respondents' data saved each time she advances to a new screen, the "Next" button at the bottom of each screen that allows respondents to proceed to the next question was changed after usability testing to read "Save \& Continue."

When issues occur in responses (such as skipped questions, likelihood values that do not properly sum to $100 \%$, etc.) respondents receive error messages called "edits" to draw their attention to these issues. ${ }^{8}$ For example, if the respondent skips all or part of a question, when she presses "Save \& Continue," red text will appear at the top of the screen asking her to please respond to all questions. All warnings also include the text "To ignore these problems, press the Save and Continue button again." ${ }^{9}$ Some participants in usability interviews did not see this second sentence and believed that they could not proceed to the next question without correcting all of the warnings. To address this concern, white space was placed between the content of the warning and the instruction for how the respondent can ignore the problem.

One important change was made to address an item-specific usability issue. The example screen added before question 30 was generally well received from a cognitive standpoint, but from a usability standpoint, many respondents tried to enter data in the example. In order for the example to be accessible under Section 508, it cannot contain a flat image file, as such a file would create a usability issue for a text to voice browser. Thus, the example had to contain a prefilled table in which the user can place her cursor within the data entry cells, although she cannot edit the pre-entered data. To make the example clearer to respondents, a bolded text box was added at the top of the screen which reads "This screen contains an example. You will be asked to complete this and similar questions on the next four screens."

Other usability concerns were identified during testing but the desired changes could not be implemented due to the time constraints and the need to prioritize changes to the electronic instrument. For example, once respondents have viewed all screens containing survey content,

\footnotetext{
${ }^{7}$ Questions 3, 4, 9, 11, 27, 28, and 29. Note that for the 2010 MOPS, this restriction was in place.

${ }^{8}$ We refer to "edits" as "warnings" for clarity.

${ }^{9}$ Because respondents can choose to ignore the warnings, these warnings are considered "soft edits." For more information on soft edits, see Buffington, Hennessy, and Ohlmacher (forthcoming).
} 
they are presented with a review screen. This review screen has a very basic presentation, with a list of all 47 question screens and the number of errors on each screen in parenthesis next to the names of the screens (Figure 1a). The ASM, for which the MOPS is a supplement with the same mail sample, has a much richer interface: questions are listed in a table, and the status of each question is listed in the table with clear graphics and color-coding (Figure 1b). Although a review screen analogous to the ASM review screen was desired for MOPS, the MOPS 2015 instrument was created based on the MOPS 2010 web instrument. At the time that the MOPS 2010 instrument was created, the more developed review screen was unavailable, and once the issues with the MOPS 2015 review screen were discovered during usability testing, it was too late to introduce this feature.

Several cognitive issues were identified during usability testing and later addressed. In particular, the order of parts (a) and (b) within questions 27 and 28 were reversed when compared to the other question in this survey. These questions asked about 2015 before they asked about 2010, whereas the rest of the survey asks about 2010 and then 2015, at least on the electronic instrument. (On the paper instrument, 2010 responses come "first" as they are to the left of 2015 responses.) During usability testing, the different order of these questions confused some interviewees and thus the order was changed in the electronic instrument to create consistency with the rest of the survey; it was too late in the survey development process to change the paper instrument. See Figure 2 for a comparison between the paper versions of these questions and their electronic counterparts.

Additionally, the "Frequently Asked Questions” (FAQ) page on the MOPS Business Help Site (BHS) was developed in part based on cognitive findings from the usability testing. ${ }^{10}$ Specifically, definitions were introduced for the key terms in questions 30-37 such as "products shipped" and "materials, parts, containers, and packaging." These definitions, like the key terms themselves, are identical to the terminology used on the ASM. In fact, the language used in the FAQ is limited to language that is in use on the MOPS instrument (and therefore tested) or is consistent with the materials (BHS, instruments, instructions) for other Census surveys.

Not all cognitive findings from the usability testing were incorporated into changes in the electronic instrument. For example, respondents at new businesses were unsure how to complete the questions with recall components. If responses were not provided for reference year 2010 questions, then a warning would be generated even if the establishment was not in business in 2010. The staff from DCMRB suggested either dropping the recall component or introducing a screening question (which would not allow responses for 2010 for those establishments that were

\footnotetext{
${ }^{10}$ https://bhs.econ.census.gov/bhs/mops/faq.html
} 
not active in 2010). Since recall is an important part of the MOPS, dropping was not considered and introducing a screening question was not feasible given time constraints.

Instead, as noted above, the spacing of the warnings was changed to make it clear that respondents have the option of ignoring warnings. Additionally, language was added to the FAQ page on the BHS providing answers to the questions "My establishment was not in business in 2010. What should I do?” and "I was not an employee at this establishment in 2010. What should I do?” This FAQ information was also provided to clerks at the National Processing Center who fielded questions from respondents. However, researchers should be aware that some respondents who responded electronically may have felt compelled to enter recall data even if the establishment was not in business or the quality of the recall data was very low.

Further, DCMRB suggested dropping Section D from the MOPS based on cognitive findings from the usability testing. Because the questions have been shown to be successful by the Federal Reserve Bank of Atlanta and are considered a key part of the MOPS 2015, this recommendation was declined. Respondents generally found the example at the start of Section $\mathrm{D}$ to be helpful during usability testing, except in cases where they did not realize that it was an example. As noted above, a textbox was introduced after testing on the example screen for the electronic instrument to draw respondents' attention to the example and further increase the example’s efficacy.

Although not all recommendations gathered from cognitive and usability testing were implemented due to time and space constraints and the preferences of the survey sponsors to generally preserve comparability across statistical periods and with other similar survey instruments, the MOPS 2015 was revised significantly to enhance the quality of responses received when the survey went into the field.

\section{Conclusion}

The MOPS instrument was developed over an iterative process. In keeping with the Census Bureau's quality standards, the instruments for the 2010 and 2015 MOPS were each subject to multiple rounds of pretesting. The MOPS 2010 underwent internal expert review and two rounds of cognitive testing before being released into the field. New questions for the MOPS 2015 also underwent two rounds of cognitive testing and the full MOPS 2015 web instrument was tested for usability.

Through these rounds of testing, recommendations from experts, specialists, and respondents were used to hone the survey into the form that would ultimately be mailed to respondents for collection. Not every recommendation was incorporated into the final survey instruments due to time and resource constraints and incompatibility with the survey content goals. Every effort was made to use the insights provided by the pretesting processes to improve the MOPS instruments. 


\section{References}

Brynjolfsson, Erik, Lorin M. Hitt, and Heekyung Hellen Kim (2011), 'Strength in Numbers: How Does Data-Driven Decisionmaking Affect Firm Performance?' SSRN Working Paper 1819486.

Buffington, Cathy, Lucia Foster, Ron Jarmin, and Scott Ohlmacher (2016), 'The Management and Organizational Practices Survey (MOPS): An Overview,' CES Working Paper 16-28.

Buffington, Cathy, Andrew Hennessy, and Scott Ohlmacher (forthcoming), 'The Management and Organizational Practices Survey (MOPS): Collection and Processing,' CES Working Paper.

Gerver, Miriam and La Toya Thomas (2009), 'Expert Review of ASM Management Practices Supplement,' internal Census Bureau documentation.

Herrell, Kenny and Krysten Mesner (2016), 'Findings and Recommendations from Usability Testing for the Management and Organizational Practices Survey,’ internal Census Bureau documentation.

Pick, Kenneth and Michael Brennan (2015a), 'Findings and Recommendations from Round One Cognitive Testing for the 2015 Management and Organizational Practices Survey (MOPS),' internal Census Bureau documentation.

Pick, Kenneth and Michael Brennan (2015b), 'Findings and Recommendations from the Second Round of Cognitive Testing for the 2015 Management and Organizational Practices Survey (MOPS),' internal Census Bureau documentation.

Stettler, Kristin (2011), 'Summary of Basic Findings from Expert Review and Cognitive Testing of the Management and Organizational Practices Survey,' internal Census Bureau documentation.

Tuttle, A. David (2011), 'Findings and Recommendations from Usability Testing for the Management and Organizational Practices Survey,’ internal Census Bureau documentation. 


\section{Figure 1. Web Review Screens for MOPS 2015 and ASM 2014}

\section{Figure 1a. MOPS 2015 Web Review Screen}

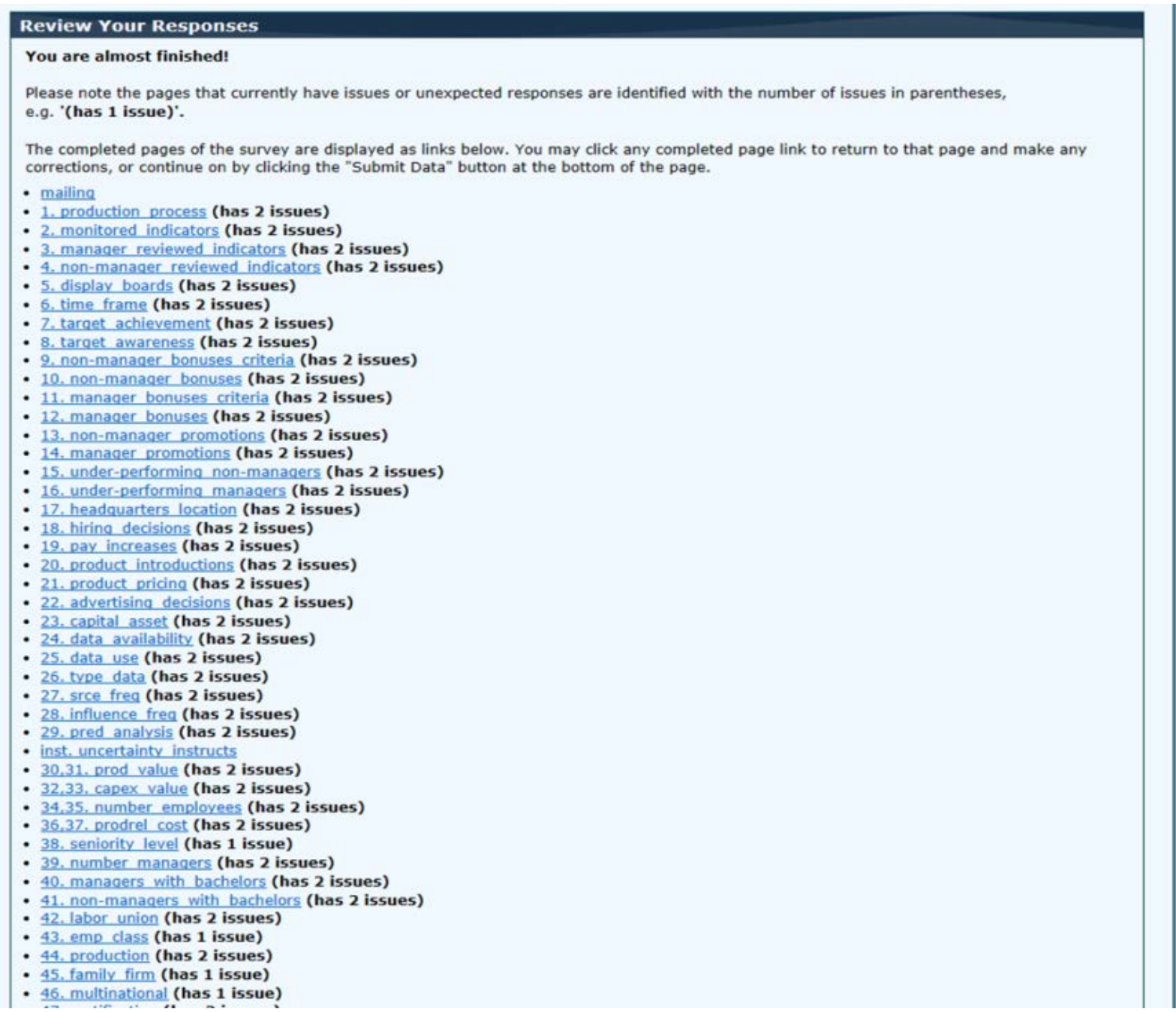


Figure 1b. ASM 2014 Web Review Screen

Please use the links below to review and correct any questions having warnings and $e$ You will not be able to submit your data to the Census Bureau with errors.

\begin{tabular}{|c|c|c|}
\hline Title & \multicolumn{2}{|c|}{ Status } \\
\hline Mailing Address & (2) & Ok \\
\hline Employer Identification Number Validation & (1) & Warnings \\
\hline Ownership Or Control & (2) & Ok \\
\hline Ownership Or Control: Votina Stock Validation & (2) & Ok \\
\hline Ownership Or Control: Company Information & (1) & Warnings \\
\hline Number of Establishments & (-) & Ok \\
\hline Additional Establishments & (C) & Ok \\
\hline Added Establishment Instructions & (2) & Ok \\
\hline Physical Location Validation & (1) & Warnings \\
\hline Physical Location Information & $\boldsymbol{x}$ & Errors \\
\hline Legal Boundary and Municipality & (1) & Warnings \\
\hline Operational Status & $凶$ & Errors \\
\hline Months In Operation & (4) & Warnings \\
\hline Additional Reportina Guidelines & (2) & Ok \\
\hline Sales Shipments Receipts Or Revenue & $\boldsymbol{x}$ & Errors \\
\hline Exports & (2) & Ok \\
\hline Products Shipped for Further Manufacture & (c) & ok \\
\hline E Shipments & (1) & Warnings \\
\hline
\end{tabular}




\section{Figure 2. Questions 27 and 28 - Paper vs. Electronic}

\section{Figure 2a. Paper Form}

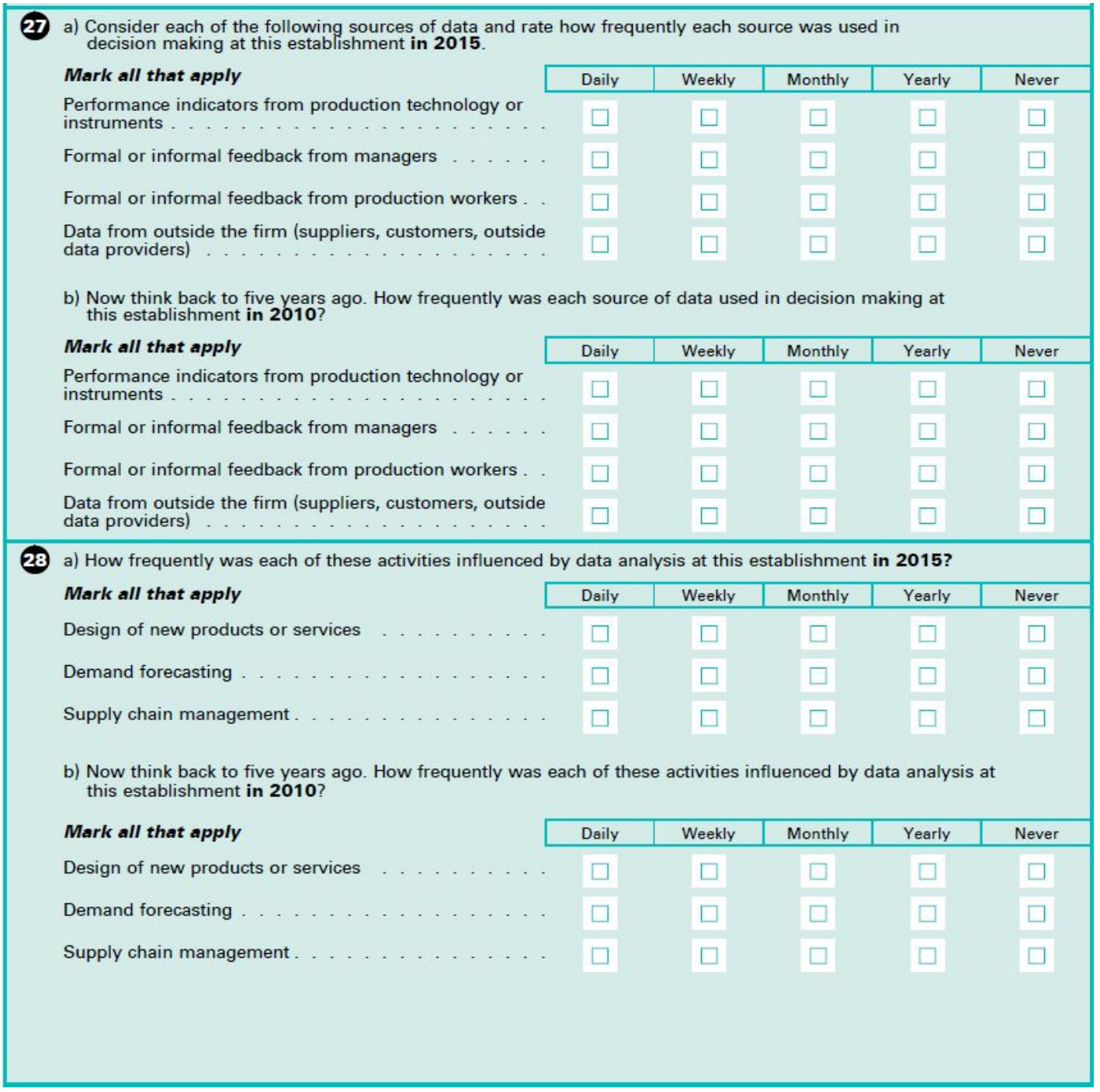


Figure 2b. Electronic Instrument

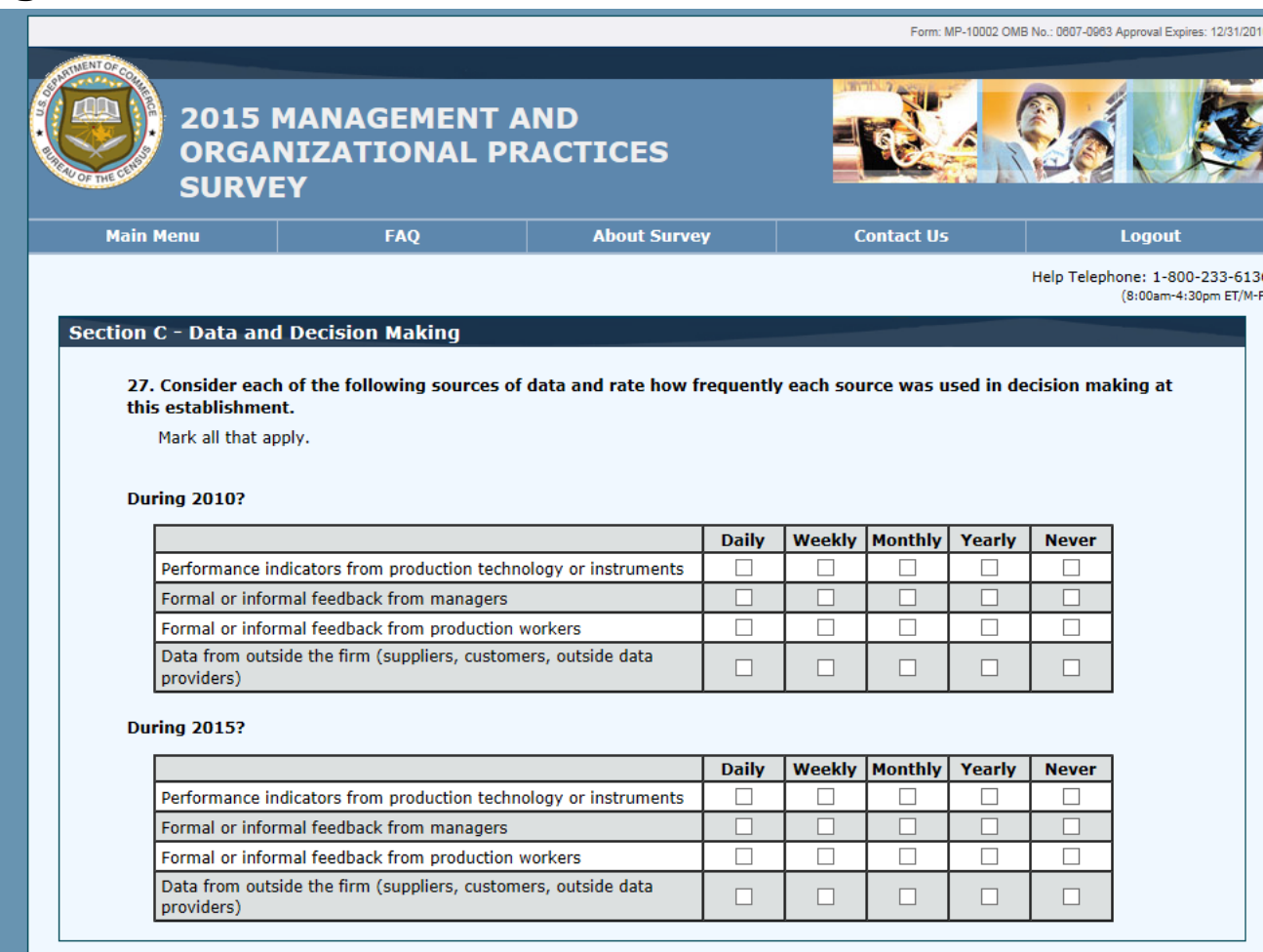

Previous Save and Continue

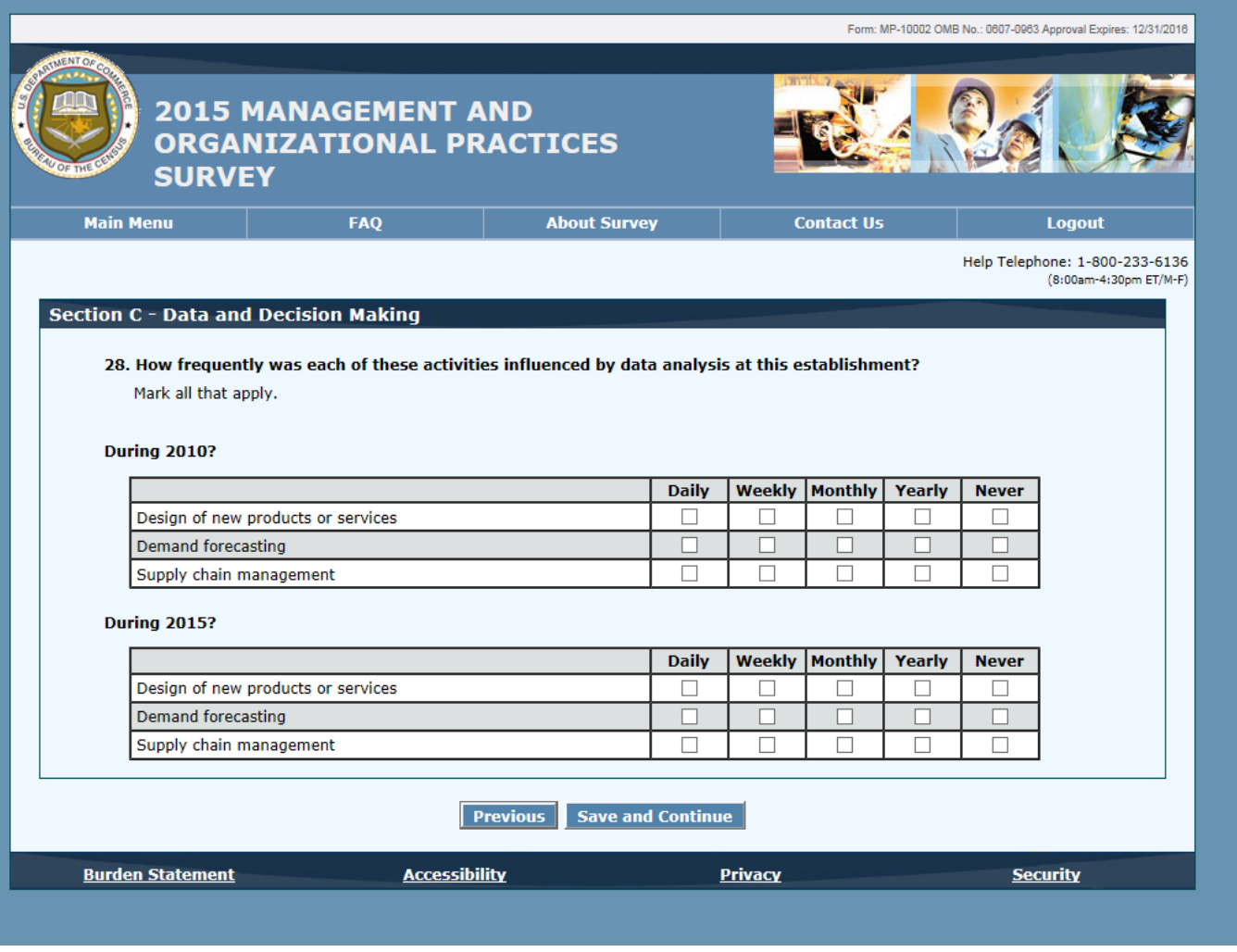


Table 1. Recommendations from expert review of the MOPS 2010 survey instrument

\begin{tabular}{|c|c|c|c|}
\hline $\begin{array}{l}\text { Question } \\
\text { Number }\end{array}$ & Recommendation & Accepted? & Notes \\
\hline 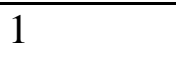 & Consider rewording to minimize social desirability bias & $\mathrm{N}$ & \\
\hline 2 & Consider rewording to minimize social desirability bias & $\mathrm{N}$ & \\
\hline 3 & $\begin{array}{l}\text { Consider prefacing this question with an instruction regarding } \\
\text { which performance indicator should be used to answer this } \\
\text { question if different KPIs could be collected with different } \\
\text { frequencies. }\end{array}$ & $\mathrm{N}$ & \\
\hline 4 & $\begin{array}{l}\text { Consider prefacing this question with an instruction regarding } \\
\text { which performance indicator should be used to answer this } \\
\text { question if different KPIs could be collected with different } \\
\text { frequencies. }\end{array}$ & $\mathrm{N}$ & \\
\hline \multicolumn{4}{|l|}{5} \\
\hline 6 & $\begin{array}{l}\text { Remove language "Balanced focus on both short- and long-term } \\
\text { production targets" due to social desirability issues. }\end{array}$ & $\mathrm{Y}$ & Changed to "combination" \\
\hline 7 & $\begin{array}{l}\text { Change to a Likert scale rather than "impossible", "easy", } \\
\text { "demanding for some", and "demanding for all." }\end{array}$ & $\mathrm{Y}$ & \\
\hline \multicolumn{4}{|l|}{8} \\
\hline \multicolumn{4}{|l|}{9} \\
\hline \multicolumn{4}{|l|}{10} \\
\hline \multicolumn{4}{|l|}{11} \\
\hline \multicolumn{4}{|l|}{12} \\
\hline 13 & Include examples other than tenure, including negative factors & $\mathrm{Y}$ & Added "family connections" \\
\hline 14 & Include examples other than tenure, including negative factors & $\mathrm{Y}$ & Added "family connections" \\
\hline
\end{tabular}


U.S. Census Bureau

Expert Review - MOPS 2010

\begin{tabular}{|c|c|c|c|}
\hline $\begin{array}{l}\text { Question } \\
\text { Number }\end{array}$ & Recommendation & Accepted? & Notes \\
\hline 15 & Reword to minimize social desirability bias & $\mathrm{Y}$ & $\begin{array}{l}\text { Changed from "Underperforming } \\
\text { employees are rarely or never moved } \\
\text { from their position", "Underperforming } \\
\text { employees usually stay in their position } \\
\text { for at least a year before action is taken", } \\
\text { and "Underperforming employees are } \\
\text { rapidly helped and re-trained, and then } \\
\text { moved out of the company if their } \\
\text { performance does not improve" }\end{array}$ \\
\hline 16 & Reword to minimize social desirability bias & $\mathrm{Y}$ & See question 15 \\
\hline 17 & & & \\
\hline 18 & & & \\
\hline 19 & & & \\
\hline 20 & & & \\
\hline 21 & & & \\
\hline 22 & & & \\
\hline 23 & & & \\
\hline 24 & & & \\
\hline 25 & & & \\
\hline 26 & & & \\
\hline 27 & & & \\
\hline 28 & & & \\
\hline 29 & & & \\
\hline 30 & & & \\
\hline 31 & & & \\
\hline
\end{tabular}


U.S. Census Bureau

Expert Review - MOPS 2010

\begin{tabular}{|c|c|c|c|}
\hline $\begin{array}{l}\text { Question } \\
\text { Number }\end{array}$ & Recommendation & Accepted? & Notes \\
\hline 32 & $\begin{array}{l}\text { Use standard measurement term from Federal agencies "pay } \\
\text { period that includes March 12." }\end{array}$ & $\mathrm{Y}$ & \\
\hline 33 & $\begin{array}{l}\text { Use standard measurement term from Federal agencies "pay } \\
\text { period that includes March 12." }\end{array}$ & $\mathrm{Y}$ & \\
\hline \multicolumn{4}{|l|}{34} \\
\hline \multicolumn{4}{|l|}{35} \\
\hline \multicolumn{4}{|l|}{36} \\
\hline \multirow[t]{4}{*}{$\begin{array}{l}\text { General } \\
\text { Remarks }\end{array}$} & Change the "check the box" language into direct questions. & $\mathrm{Y}$ & $\begin{array}{l}\text { All questions are formatted as direct } \\
\text { questions. }\end{array}$ \\
\hline & $\begin{array}{l}\text { Include a statement about estimates being acceptable for each } \\
\text { question that requires a numeric response. }\end{array}$ & $\mathrm{Y}$ & \\
\hline & $\begin{array}{l}\text { Do not ask for recall data. The burden is too high because it } \\
\text { requires respondents to do twice the amount of work for nearly } \\
\text { every question. If the respondent was not in the same position in } \\
\text { 2005, they may attempt to distribute the survey to others who can } \\
\text { answer for that year. That leads to having multiple respondents } \\
\text { and increased burden. If respondents choose not to distribute the } \\
\text { survey, they may report more accurately for } 2010 \text { than for 2005, } \\
\text { thus resulting in measurement error for the } 2005 \text { data. }\end{array}$ & $\mathrm{N}$ & \\
\hline & $\begin{array}{l}\text { Add the phrase "during 2010" to the question to reinforce the } \\
\text { reference year. }\end{array}$ & $\mathrm{Y}$ & $\begin{array}{l}\text { Added "in } 2005 \text { and 2010" to the } \\
\text { beginning of each question stem. }\end{array}$ \\
\hline
\end{tabular}


U.S. Census Bureau

Expert Review - MOPS 2010

\begin{tabular}{|l|l|l|l|}
\hline $\begin{array}{l}\text { Question } \\
\text { Number }\end{array}$ & Recommendation & Accepted? & Notes \\
\hline \hline & $\begin{array}{l}\text { For questions with response options that indicate negation, like } \\
\text { "None” or "No...," place them last in the response option list, } \\
\text { particularly those including a skip pattern. This will avoid } \\
\text { distracting respondents from reading through the rest of the } \\
\text { response options or inaccurately answering in order to move } \\
\text { through the form faster }\end{array}$ & & \\
\hline & Group similar questions together & Y & \\
\hline
\end{tabular}

Note: This table was developed based on Gerver and Thomas (2009). 
US Census Bureau

Cognitive Testing - MOPS 2010

Table 2. Recommendations from cognitive testing of the MOPS 2010 survey instrument

\begin{tabular}{|c|c|c|c|}
\hline $\begin{array}{l}\text { Question } \\
\text { Number }\end{array}$ & Recommendation & Accepted? & Notes \\
\hline 1 & $\begin{array}{l}\text { If different problems have different processes, then that is not captured } \\
\text { in these response options. In the example, "finding a quality defect in a } \\
\text { product" and "a piece of machinery breaking down" could have two } \\
\text { completely different solutions. }\end{array}$ & $\mathrm{N}$ & \\
\hline 2 & "Cost" should be added as an example of a KPI & $\mathrm{Y}$ & \\
\hline \multirow[t]{2}{*}{3} & $\begin{array}{l}\text { Definition of manager tricky. Some use other terms or define } \\
\text { differently. Pay and promotions seemed very limiting - better to say } \\
\text { involved in the daily supervision/management of productivity/work. }\end{array}$ & $\mathrm{Y}$ & $\begin{array}{l}\text { Changed definition of manager } \\
\text { from "A manager is someone who } \\
\text { is involved in pay and promotions } \\
\text { for employees who work for them. } \\
\text { e.g. Plant Manager, Human } \\
\text { Resource Manager, Quality } \\
\text { Manager)" to "A manager is } \\
\text { someone who has employees } \\
\text { directly reporting to them, with } \\
\text { whom they meet on a regular basis, } \\
\text { and whose pay and promotion they } \\
\text { may be involved with, e.g., Plant } \\
\text { Manager, Human Resource } \\
\text { Manager, Quality Manager." }\end{array}$ \\
\hline & 3 out of 5 didn't realize they could check more than one. & $\mathrm{Y}$ & Bold "Mark all that apply." \\
\hline \multicolumn{4}{|l|}{4} \\
\hline 5 & $\begin{array}{l}\text { People understood this question and the response options, but pointed } \\
\text { out that it does not include other ways of sharing information, such as } \\
\text { newsletters and electronic databases. }\end{array}$ & $\mathrm{N}$ & \\
\hline
\end{tabular}


US Census Bureau

Cognitive Testing - MOPS 2010

\begin{tabular}{|c|c|c|c|}
\hline $\begin{array}{l}\text { Question } \\
\text { Number }\end{array}$ & Recommendation & Accepted? & Notes \\
\hline \multicolumn{4}{|l|}{6} \\
\hline 7 & $\begin{array}{l}\text { There was a mismatch between the percentages and the easy/difficulty } \\
\text { descriptions. That is, respondents could have hit their targets } 90-99 \% \\
\text { of the time, but it was not necessarily "somewhat easy.” People seemed } \\
\text { to focus on the percentages, but then didn't know how to respond once } \\
\text { they read the descriptions. }\end{array}$ & $Y$ & $\begin{array}{l}\text { Early versions of this question had } \\
\text { response items such as "Neither } \\
\text { easy nor difficult (we hit our targets } \\
50 \% \text { to } 90 \% \text { of the time)." Changed } \\
\text { to scale relative to "normal effort." } \\
\text { This change tested well during the } \\
\text { second round of cognitive testing. }\end{array}$ \\
\hline \multicolumn{4}{|l|}{8} \\
\hline 9 & & & $\begin{array}{l}\text { Bold "Mark all that apply" based on } \\
\text { feedback from Q3, introduced in } \\
\text { response to feedback to question } \\
10 .\end{array}$ \\
\hline 10 & $\begin{array}{l}\text { It was not clear whether "performance” referred to individual } \\
\text { performance or to plant/company performance (the equivalent of being } \\
\text { profitable, having a good amount of revenue, year-end results of the } \\
\text { company, etc.). Most people understood this to mean "individual } \\
\text { performance.” }\end{array}$ & $\mathrm{Y}$ & $\begin{array}{l}\text { Introduced question } 9 \text { to determine } \\
\text { the basis for performance bonuses. }\end{array}$ \\
\hline 11 & & & $\begin{array}{l}\text { Bold "Mark all that apply" based on } \\
\text { feedback from Q3, introduced in } \\
\text { response to feedback to question } \\
12 .\end{array}$ \\
\hline 12 & See Question 10. & $\mathrm{Y}$ & $\begin{array}{l}\text { Introduced question } 11 \text { to determine } \\
\text { the basis for performance bonuses. }\end{array}$ \\
\hline 13 & Add a response for "none." & $\mathrm{Y}$ & $\begin{array}{l}\text { Added "Non-managers are not } \\
\text { normally promoted." }\end{array}$ \\
\hline
\end{tabular}


US Census Bureau

Cognitive Testing - MOPS 2010

\begin{tabular}{|c|c|c|c|}
\hline $\begin{array}{l}\text { Question } \\
\text { Number }\end{array}$ & Recommendation & Accepted? & Notes \\
\hline 13 & & & $\begin{array}{l}\text { In some cases, respondents showed } \\
\text { negative social desirability bias in } \\
\text { reaction to "family connections." }\end{array}$ \\
\hline 14 & Add a response for "none." & $\mathrm{Y}$ & $\begin{array}{l}\text { Added "Managers are not normally } \\
\text { promoted." }\end{array}$ \\
\hline 14 & & & $\begin{array}{l}\text { In some cases, respondents showed } \\
\text { negative social desirability bias in } \\
\text { reaction to "family connections." }\end{array}$ \\
\hline 15 & & & $\begin{array}{l}\text { Split from "employee" into } \\
\text { "managers" and "non-managers" } \\
\text { after second round of cognitive } \\
\text { testing. }\end{array}$ \\
\hline 16 & & & See question 15 \\
\hline 17 & $\begin{array}{l}\text { Some respondents had trouble with this question - they thought that we } \\
\text { were asking if the headquarters had moved between } 2005 \text { and } 2010 \text {. }\end{array}$ & $\mathrm{N}$ & $\begin{array}{l}\text { This issue was present again in } \\
\text { 2015. See Table } 3 \text {. }\end{array}$ \\
\hline \multicolumn{4}{|l|}{18} \\
\hline \multicolumn{4}{|l|}{19} \\
\hline \multicolumn{4}{|l|}{20} \\
\hline \multicolumn{4}{|l|}{21} \\
\hline \multicolumn{4}{|l|}{22} \\
\hline 23 & & & $\begin{array}{l}\text { Options "Authorization required for } \\
\text { all purchases" and "\$1 to } \$ 999 " \\
\text { were combined into "Under } \$ 1,000 "\end{array}$ \\
\hline
\end{tabular}


US Census Bureau

Cognitive Testing - MOPS 2010

\begin{tabular}{|c|c|c|c|}
\hline $\begin{array}{l}\text { Question } \\
\text { Number }\end{array}$ & Recommendation & Accepted? & Notes \\
\hline 24 & & & $\begin{array}{l}\text { "Number of direct reports" was } \\
\text { changed to "number of employees } \\
\text { reporting directly to the plant } \\
\text { manager." Definition still refers to } \\
\text { "direct reports." This question did } \\
\text { not perform well in the field and } \\
\text { was dropped from MOPS } 2015 .\end{array}$ \\
\hline 25 & $\begin{array}{l}\text { There can be different numbers of levels on the factory floor if there are } \\
\text { different departments within a single factory floor. The person who had } \\
\text { this assumed that we wanted the chain with the most number of levels. }\end{array}$ & $\mathrm{N}$ & $\begin{array}{l}\text { This question did not perform well } \\
\text { in the field and was dropped from } \\
\text { MOPS } 2015 \text {. }\end{array}$ \\
\hline 26 & $\begin{array}{l}\text { There was some confusion about what the word "workers” meant. They } \\
\text { thought that "plant floor workers" or "production workers" would } \\
\text { clarify this word. }\end{array}$ & $\mathrm{Y}$ & $\begin{array}{l}\text { "Workers" changed to "production } \\
\text { workers." This question did not } \\
\text { perform well in the field and was } \\
\text { dropped from MOPS } 2015 .\end{array}$ \\
\hline 27 & & & $\begin{array}{l}\text { Not tested in 2010. Question was } \\
\text { added after cognitive testing was } \\
\text { complete. }\end{array}$ \\
\hline 28 & & & $\begin{array}{l}\text { Not tested in 2010. Question was } \\
\text { added after cognitive testing was } \\
\text { complete. }\end{array}$ \\
\hline 29 & & & $\begin{array}{l}\text { "Trade associations or conferences" } \\
\text { was added at the suggestion of a } \\
\text { participant in cognitive testing } \\
\text { interviews. This question did not } \\
\text { perform well in the field and was } \\
\text { dropped from MOPS } 2015 \text {. }\end{array}$ \\
\hline
\end{tabular}


US Census Bureau

Cognitive Testing - MOPS 2010

\begin{tabular}{|c|c|c|c|}
\hline $\begin{array}{l}\text { Question } \\
\text { Number }\end{array}$ & Recommendation & Accepted? & Notes \\
\hline 30 & & & $\begin{array}{l}\text { This question was dropped from } \\
\text { MOPS } 2015 .\end{array}$ \\
\hline \multicolumn{4}{|l|}{31} \\
\hline \multicolumn{4}{|l|}{32} \\
\hline \multicolumn{4}{|l|}{33} \\
\hline \multicolumn{4}{|l|}{34} \\
\hline \multicolumn{4}{|l|}{35} \\
\hline 36 & Add $0 \%$ as a response and change " $20 \%$ or less" to " $1 \%-20 \%$ " & $\mathrm{Y}$ & \\
\hline 36 & & & $\begin{array}{l}\text { Unionization was frequently } \\
\text { reported as a key component of } \\
\text { incentives practices, and this } \\
\text { question was introduced after the } \\
\text { first round of cognitive testing. }\end{array}$ \\
\hline \multirow[t]{3}{*}{$\begin{array}{l}\text { General } \\
\text { Remarks }\end{array}$} & $\begin{array}{l}\text { One person missed that we were asking for both } 2005 \text { and } 2010 \text { data - } \\
\text { maybe state that on the front page }\end{array}$ & $\mathrm{N}$ & \\
\hline & $\begin{array}{l}\text { Asking about } 2005 \text { and } 2010 \text { was generally ok, though respondents } \\
\text { would like to be reassured they can estimate or leave blank if they're } \\
\text { not comfortable. Some said they weren't there that long ago and } \\
\text { couldn't provide it; others said that even if they didn't know the } \\
\text { information themselves, they could get it from someone else, for } \\
\text { example someone in Operations, Quality Control, or HR. }\end{array}$ & $\mathrm{Y}$ & $\begin{array}{l}\text { The following language was } \\
\text { included on the letter that } \\
\text { accompanied the MOPS } 2010 \\
\text { instrument in the mail: "Estimates } \\
\text { are acceptable when responding to } \\
\text { questions on this report form.” }\end{array}$ \\
\hline & $\begin{array}{l}\text { Should have a brief blurb on the front cover stating what the survey is } \\
\text { about. }\end{array}$ & $\mathrm{N}$ & $\begin{array}{l}\text { No additional information about the } \\
\text { survey was included in the insert, } \\
\text { letter, or form. Implemented in } \\
\text { letters for } 2015 \text {. }\end{array}$ \\
\hline
\end{tabular}


US Census Bureau

Cognitive Testing - MOPS 2010

\begin{tabular}{|l|l|l|l|}
\hline $\begin{array}{l}\text { Question } \\
\text { Number }\end{array}$ & Recommendation & Accepted? & Notes \\
\hline \hline Cover & & & This change was adopted on the \\
Letter & Respondents prefer an actual due date to "within 30 days." & N & MOPS 2015 \\
\hline
\end{tabular}

Note: This table is based on Stettler (2011), notes from the RIRS staff and observers, and changes in the MOPS instrument. Because Stettler (2011) contains neither an exhaustive list of recommendations nor resolutions to the recommendations, this table may not include all recommendations made as a result of cognitive testing of the MOPS 2010 instrument. 
US Census Bureau

Usability Testing - MOPS 2010

Table 3. Recommendations from usability testing of the MOPS 2010 survey instrument

\begin{tabular}{|c|c|c|c|}
\hline $\begin{array}{l}\text { Question } \\
\text { Number }\end{array}$ & Recommendation & Accepted? & Notes \\
\hline $\begin{array}{l}\text { Login } \\
\text { Screen }\end{array}$ & $\begin{array}{l}\text { Enlarge the paper form illustration. Consider adding carriage } \\
\text { returns above and below the "time-out/no data lost” instruction to } \\
\text { make it more noticeable. Consider enlarging the "warning” text } \\
\text { at the bottom of the screen. }\end{array}$ & & \\
\hline \multicolumn{4}{|l|}{ Main Menu } \\
\hline \multicolumn{4}{|l|}{1} \\
\hline \multicolumn{4}{|l|}{2} \\
\hline \multicolumn{4}{|l|}{3} \\
\hline \multicolumn{4}{|l|}{4} \\
\hline \multicolumn{4}{|l|}{5} \\
\hline \multicolumn{4}{|l|}{6} \\
\hline \multicolumn{4}{|l|}{7} \\
\hline \multicolumn{4}{|l|}{8} \\
\hline \multicolumn{4}{|l|}{8} \\
\hline \multicolumn{4}{|l|}{9} \\
\hline \multicolumn{4}{|l|}{10} \\
\hline \multicolumn{4}{|l|}{11} \\
\hline \multicolumn{4}{|l|}{12} \\
\hline \multicolumn{4}{|l|}{13} \\
\hline \multicolumn{4}{|l|}{13} \\
\hline \multicolumn{4}{|l|}{14} \\
\hline \multicolumn{4}{|l|}{15} \\
\hline \multicolumn{4}{|l|}{16} \\
\hline 17 & & & \\
\hline
\end{tabular}


US Census Bureau

Usability Testing - MOPS 2010

\begin{tabular}{|c|c|c|c|}
\hline $\begin{array}{l}\text { Question } \\
\text { Number }\end{array}$ & Recommendation & Accepted? & Notes \\
\hline \multicolumn{4}{|l|}{18} \\
\hline \multicolumn{4}{|l|}{19} \\
\hline \multicolumn{4}{|l|}{20} \\
\hline \multicolumn{4}{|l|}{21} \\
\hline \multicolumn{4}{|l|}{22} \\
\hline \multicolumn{4}{|l|}{23} \\
\hline \multicolumn{4}{|l|}{24} \\
\hline \multicolumn{4}{|l|}{25} \\
\hline \multicolumn{4}{|l|}{26} \\
\hline \multicolumn{4}{|l|}{27} \\
\hline \multicolumn{4}{|l|}{27} \\
\hline \multicolumn{4}{|l|}{28} \\
\hline \multicolumn{4}{|l|}{29} \\
\hline \multicolumn{4}{|l|}{30} \\
\hline \multicolumn{4}{|l|}{31} \\
\hline \multicolumn{4}{|l|}{32} \\
\hline \multicolumn{4}{|l|}{33} \\
\hline \multicolumn{4}{|l|}{34} \\
\hline \multicolumn{4}{|l|}{34} \\
\hline \multicolumn{4}{|l|}{35} \\
\hline \multicolumn{4}{|l|}{36} \\
\hline $\begin{array}{l}\text { Remarks/ } \\
\text { Certification }\end{array}$ & $\begin{array}{l}\text { Add a simple instruction next to the response field labels for } \\
\text { "Telephone” and "Fax" to indicate that the cursor will } \\
\text { automatically advance, e.g., "Telephone: (auto-tab enabled)” or } \\
\text { some other appropriate and concise terminology. }\end{array}$ & $\mathrm{N}$ & \\
\hline
\end{tabular}


US Census Bureau

Usability Testing - MOPS 2010

\begin{tabular}{|c|c|c|c|}
\hline $\begin{array}{l}\text { Question } \\
\text { Number }\end{array}$ & Recommendation & Accepted? & Notes \\
\hline $\begin{array}{l}\text { Review } \\
\text { Screen }\end{array}$ & $\begin{array}{l}\text { Add a "view/print form as pdf" button to the review screen. Add } \\
\text { an instruction adjacent to the button indicating that the pdf will } \\
\text { only contain what was reported and will not indicate which items } \\
\text { still have problems, and that it should be used in conjunction } \\
\text { with the review page. }\end{array}$ & & \\
\hline \multirow[t]{3}{*}{$\begin{array}{l}\text { General } \\
\text { Remarks }\end{array}$} & $\begin{array}{l}\text { Add a list of screens in the form of a drop-down box, between } \\
\text { the "next/previous" buttons. }\end{array}$ & $\mathrm{N}$ & \\
\hline & $\begin{array}{l}\text { Consider adding instructions to the log-in page and/or to the } \\
\text { frequently-asked-questions (if not already there), indicating that } \\
\text { users’ browser settings may interfere with } \\
\text { page formatting, and that pressing the "control” and “+” keys } \\
\text { together will enlarge the appearance of the page. }\end{array}$ & $\mathrm{N}$ & \\
\hline & $\begin{array}{l}\text { Remove the instructions to select only one response. Retain the } \\
\text { "select all that apply" instructions but remove the parentheses } \\
\text { and place them in a more prominent position on the screens. } \\
\text { Ideally, this instruction should be placed within the typical visual } \\
\text { path (which it currently is) but surrounded by enough empty } \\
\text { space to make it stand out. One way this can be achieved is by } \\
\text { adding an extra carriage return above and below the instruction } \\
\text { where it is currently located to add space between it and the text } \\
\text { above and below it. Also, print the "select all" instruction in } \\
\text { bold. }\end{array}$ & $\mathrm{N}$ & $\begin{array}{l}\text { The "select all" instructions were printed in } \\
\text { bold with additional empty space. }\end{array}$ \\
\hline
\end{tabular}


US Census Bureau

Cognitive Testing - MOPS 2015

Table 4. Recommendations from cognitive testing of the MOPS 2015 survey instrument

\begin{tabular}{|c|c|c|c|}
\hline $\begin{array}{l}\text { Question } \\
\text { Number }\end{array}$ & Recommendation & Accepted? & Notes \\
\hline \multicolumn{4}{|l|}{$\overline{1} 1$} \\
\hline \multicolumn{4}{|l|}{2} \\
\hline \multicolumn{4}{|l|}{3} \\
\hline \multicolumn{4}{|l|}{4} \\
\hline \multicolumn{4}{|c|}{5} \\
\hline \multicolumn{4}{|l|}{6} \\
\hline \multicolumn{4}{|l|}{7} \\
\hline \multicolumn{4}{|l|}{8} \\
\hline \multicolumn{4}{|l|}{9} \\
\hline \multicolumn{4}{|l|}{10} \\
\hline \multicolumn{4}{|l|}{11} \\
\hline \multicolumn{4}{|l|}{12} \\
\hline \multicolumn{4}{|l|}{13} \\
\hline \multicolumn{4}{|l|}{14} \\
\hline \multicolumn{4}{|l|}{15} \\
\hline \multicolumn{4}{|l|}{16} \\
\hline 17 & $\begin{array}{l}\text { We recommend breaking out the question into two separate } \\
\text { constructs. First, ask about 2010: In 2010, was this } \\
\text { establishment physically located at the same location as the } \\
\text { headquarters for the company? Yes/No. Repeat for } 2015 \text {. }\end{array}$ & $\mathrm{N}$ & $\begin{array}{l}\text { The clause "In } 2010 \text { and 2015," was } \\
\text { removed to clarify this question. }\end{array}$ \\
\hline \multicolumn{4}{|l|}{18} \\
\hline \multicolumn{4}{|l|}{19} \\
\hline 20 & & & \\
\hline
\end{tabular}


US Census Bureau

Cognitive Testing - MOPS 2015

\begin{tabular}{|c|c|c|c|}
\hline $\begin{array}{l}\text { Question } \\
\text { Number }\end{array}$ & Recommendation & Accepted? & Notes \\
\hline \multicolumn{4}{|l|}{21} \\
\hline \multicolumn{4}{|l|}{22} \\
\hline \multicolumn{4}{|l|}{23} \\
\hline 24 & $\begin{array}{l}\text { We recommend explicitly clarifying the intent of the question } \\
\text { in the question itself. For example, if the survey's authors are } \\
\text { asking about operational data, then state "operational data” in } \\
\text { the question. If the survey's authors are asking about decision } \\
\text { making "in operations”, then again state it in the question. As } \\
\text { the question is currently worded, and based off the cognitive } \\
\text { interviews, the questions will currently collect vague answers } \\
\text { skewed towards financial data (as most respondents are } \\
\text { accountants). }\end{array}$ & $\mathrm{N}$ & $\begin{array}{l}\text { This question was not changed to maintain } \\
\text { consistency with MOPS } 2010 .\end{array}$ \\
\hline 25 & See question 24 & $\mathrm{~N}$ & See question 24 \\
\hline 26 & $\begin{array}{l}\text { If the type of data is clarified in questions } 24 \text { and 25, also } \\
\text { clarify it here in Question } 26 .\end{array}$ & $\mathrm{N}$ & $\begin{array}{l}\text { Because "data" was not clarified in } \\
\text { questions } 24 \text { and 25, it was not clarified } \\
\text { here. }\end{array}$ \\
\hline 26 & $\begin{array}{l}\text { Consider breaking out headquarters into a separate response } \\
\text { option. }\end{array}$ & $\mathrm{N}$ & $\begin{array}{l}\text { "Managers at other establishments } \\
\text { including headquarters" changed to } \\
\text { "Managers at headquarters and/or other } \\
\text { establishments" }\end{array}$ \\
\hline 27 & $\begin{array}{l}\text { We recommend clarifying the "Mark all that apply" } \\
\text { instructions if only one box should be marked per horizontal } \\
\text { response option. }\end{array}$ & $\mathrm{N}$ & $\begin{array}{l}\text { More than one mark per horizontal } \\
\text { response option is acceptable. }\end{array}$ \\
\hline 27 & Include a quarterly option separating monthly and yearly. & $\mathrm{N}$ & $\begin{array}{l}\text { Quarterly could not be added due to space } \\
\text { constraints on the paper instrument. }\end{array}$ \\
\hline
\end{tabular}


US Census Bureau

Cognitive Testing - MOPS 2015

\begin{tabular}{|c|c|c|c|}
\hline $\begin{array}{l}\text { Question } \\
\text { Number }\end{array}$ & Recommendation & Accepted? & Notes \\
\hline 27 & $\begin{array}{l}\text { Add a "not applicable” response option if it is important to } \\
\text { differentiate between "never" and "not applicable” in the data } \\
\text { analysis. }\end{array}$ & $\mathrm{N}$ & $\begin{array}{l}\text { It is not necessary to differentiate between } \\
\text { "never" and "not applicable." }\end{array}$ \\
\hline 27 & $\begin{array}{l}\text { Consider emphasizing the word "used" in the question stem to } \\
\text { emphasize the term. This can be done either by bolding the } \\
\text { word or using capital letters. }\end{array}$ & $\mathrm{N}$ & \\
\hline 28 & $\begin{array}{l}\text { We recommend clarifying the "Mark all that apply" } \\
\text { instructions if only one box should be marked per horizontal } \\
\text { response option. We also recommend including a quarterly } \\
\text { option separating monthly and yearly. }\end{array}$ & $\mathrm{N}$ & $\begin{array}{l}\text { More than one mark per horizontal } \\
\text { response option is acceptable. }\end{array}$ \\
\hline 28 & $\begin{array}{l}\text { Add a "not applicable” response option if it is important to } \\
\text { differentiate between "never" and "not applicable” in the data } \\
\text { analysis. }\end{array}$ & $\mathrm{N}$ & $\begin{array}{l}\text { It is not necessary to differentiate between } \\
\text { "never" and "not applicable." }\end{array}$ \\
\hline 28 & $\begin{array}{l}\text { The question asks, "How often..." when similar questions ask, } \\
\text { "How frequently..." We recommend changing the wording so } \\
\text { it is consistent. }\end{array}$ & $\mathrm{Y}$ & \\
\hline 29 & $\begin{array}{l}\text { We recommend clarifying the "Mark all that apply" } \\
\text { instructions if only one box should be marked per vertical } \\
\text { response option. }\end{array}$ & $\mathrm{N}$ & $\begin{array}{l}\text { More than one mark per vertical response } \\
\text { option is acceptable. }\end{array}$ \\
\hline 29 & $\begin{array}{l}\text { Add a "not applicable" response option if it is important to } \\
\text { differentiate between "never" and "not applicable” in the data } \\
\text { analysis. }\end{array}$ & $\mathrm{N}$ & $\begin{array}{l}\text { It is not necessary to differentiate between } \\
\text { "never" and "not applicable." }\end{array}$ \\
\hline 29 & Include a quarterly option separating monthly and yearly. & $\mathrm{N}$ & $\begin{array}{l}\text { Quarterly could not be added due to space } \\
\text { constraints on the paper instrument. }\end{array}$ \\
\hline 30 & $\begin{array}{l}\text { We recommend providing an example to the respondents on } \\
\text { how to complete these questions to allay any comprehension } \\
\text { concerns. }\end{array}$ & $\mathrm{Y}$ & $\begin{array}{l}\text { An example will be provided at the } \\
\text { beginning of this section }\end{array}$ \\
\hline
\end{tabular}


US Census Bureau

Cognitive Testing - MOPS 2015

\begin{tabular}{|c|c|c|c|}
\hline $\begin{array}{l}\text { Question } \\
\text { Number }\end{array}$ & Recommendation & Accepted? & Notes \\
\hline 31 & See question 30 & $\overline{\mathrm{Y}}$ & See question 30 \\
\hline 31 & $\begin{array}{l}\text { We recommend only asking for one number for 2017, since } \\
\text { single-unit establishments seem to be able to make an educated } \\
\text { guess and multi-unit establishments do forecast at least one } \\
\text { number. Having respondents break it out into multiple } \\
\text { scenarios is very confusing, especially for single-unit } \\
\text { establishments. If respondents do break it out, we would } \\
\text { question the accuracy of the data collected. }\end{array}$ & $\mathrm{N}$ & $\begin{array}{l}\text { Sponsors prefer to have } 5 \text { point forecasts, } \\
\text { which are also being fielded as a survey by } \\
\text { the Federal Reserve Bank of Atlanta. } \\
\text { Instructions were added to the beginning of } \\
\text { the section in order to address these } \\
\text { concerns. }\end{array}$ \\
\hline 32 & See question 30 & $\mathrm{Y}$ & See question 30 \\
\hline 33 & See questions $30 \& 31$ & $\mathrm{Y}$ & See questions $30 \& 31$ \\
\hline 34 & See question 30 & $\mathrm{Y}$ & See question 30 \\
\hline 35 & See questions $30 \& 31$ & $\mathrm{Y}$ & See questions $30 \& 31$ \\
\hline 36 & See question 30 & $\mathrm{Y}$ & See question 30 \\
\hline 36 & $\begin{array}{l}\text { Suggest using the category "Cost of materials, parts, containers, } \\
\text { and packaging." }\end{array}$ & $\mathrm{Y}$ & $\begin{array}{l}\text { Sponsor is interested in collecting an } \\
\text { estimate on cost of intermediate inputs, but } \\
\text { respondents are generally not familiar with } \\
\text { the term "intermediate inputs." The ASM } \\
\text { asks broadly about "Production related } \\
\text { costs," with a list of line items that are } \\
\text { aggregated to "production related costs." } \\
\text { We use the first line item, "Cost of } \\
\text { materials, parts, containers, and } \\
\text { packaging." }\end{array}$ \\
\hline 37 & See questions $30 \& 31$ & $\mathrm{Y}$ & See questions $30 \& 31$ \\
\hline 37 & $\begin{array}{l}\text { Suggest using the category "Cost of materials, parts, containers, } \\
\text { and packaging." }\end{array}$ & $\mathrm{Y}$ & See explanation from question 36. \\
\hline
\end{tabular}


US Census Bureau

Cognitive Testing - MOPS 2015

\begin{tabular}{|c|c|c|c|}
\hline $\begin{array}{l}\text { Question } \\
\text { Number }\end{array}$ & Recommendation & Accepted? & Notes \\
\hline \multicolumn{4}{|l|}{38} \\
\hline \multicolumn{4}{|l|}{39} \\
\hline \multicolumn{4}{|l|}{40} \\
\hline \multicolumn{4}{|l|}{41} \\
\hline \multicolumn{4}{|l|}{42} \\
\hline 43 & $\begin{array}{l}\text { We recommend providing definitions for flexible hours and } \\
\text { cross-trained so that respondents know how to interpret these } \\
\text { constructs and provide an appropriate response. }\end{array}$ & $\mathrm{N}$ & $\begin{array}{l}\text { The term "rotated jobs" was removed from } \\
\text { the question, which initially asked about } \\
\text { the share of workers who were "cross- } \\
\text { trained or rotated jobs," which are two } \\
\text { potentially separate categories. The world } \\
\text { "all” was added before "employees.” A line } \\
\text { for "Employees who worked from home } \\
\text { one day or more per week" was added after } \\
\text { pre-testing was complete. }\end{array}$ \\
\hline 44 & $\begin{array}{l}\text { We recommend bolding best to emphasize to respondents that } \\
\text { they should select one response. }\end{array}$ & $\mathrm{Y}$ & \\
\hline 44 & Consider adding definitions to each term. & $\mathrm{N}$ & $\begin{array}{l}\text { Cellular manufacturing often incorporates } \\
\text { continuous flow, so "continuous flow" was } \\
\text { changed to "continuous flow (other than } \\
\text { cellular manufacturing)." }\end{array}$ \\
\hline 45 & $\begin{array}{l}\text { We recommend changing family firm to "owned by a family," } \\
\text { or something similar, if the intent of the question is to capture } \\
\text { family-ownership information. We also recommend adding } \\
\text { " } 50 \% \text { or more” so respondents are able to quantify the level of } \\
\text { ownership. For example, the question could read, "Is this } \\
\text { establishment owned } 50 \% \text { or more by a family?” }\end{array}$ & $\mathrm{Y}$ & $\begin{array}{l}\text { Question text was changed from "Is this } \\
\text { establishment owned by a family firm?" } \\
\text { because respondents were often unsure } \\
\text { about the meaning of "family firm." }\end{array}$ \\
\hline
\end{tabular}


US Census Bureau

Cognitive Testing - MOPS 2015

\begin{tabular}{|c|c|c|c|}
\hline $\begin{array}{l}\text { Question } \\
\text { Number }\end{array}$ & Recommendation & Accepted? & Notes \\
\hline 46 & We recommend dropping the term "multinational." & $\mathrm{Y}$ & $\begin{array}{l}\text { Question initially read "Is this } \\
\text { establishment part of a multinational firm } \\
\text { which has production establishments in } \\
\text { other countries?" Many respondents were } \\
\text { unfamiliar with the term "multinational," } \\
\text { and there was confusion about } \\
\text { multinational firms that have operations } \\
\text { other than production in other countries. }\end{array}$ \\
\hline \multirow[t]{3}{*}{$\begin{array}{l}\text { General } \\
\text { Remarks }\end{array}$} & $\begin{array}{l}\text { Based off the feedback received from the second round of } \\
\text { cognitive testing, we recommend sending the survey invite } \\
\text { directly to the plant. It is our opinion that the plant controller } \\
\text { will most likely complete the survey, and/or work with the } \\
\text { plant manager to complete the survey. Nonresponse follow-up } \\
\text { should be directed to the corporate offices if the plant fails to } \\
\text { respond. }\end{array}$ & $\mathrm{Y}$ & $\begin{array}{l}\text { This is the methodology followed by both } \\
\text { the MOPS } 2010 \text { and MOPS 2015, which is } \\
\text { relatively unique among Census Bureau } \\
\text { surveys }\end{array}$ \\
\hline & $\begin{array}{l}\text { We recommend providing guidance on the form tailored to } \\
\text { respondents who were not employed in } 2010 \text { at the } \\
\text { establishment on how to answer these historical opinion-based } \\
\text { questions (i.e., estimates are acceptable, etc.). Having explicit } \\
\text { instructions may decrease item nonresponse. }\end{array}$ & $\mathrm{N}$ & $\begin{array}{l}\text { "Estimates are acceptable when responding } \\
\text { to questions on this report form" will be } \\
\text { included on the letter, as with the MOPS } \\
2010 .\end{array}$ \\
\hline & $\begin{array}{l}\text { We recommended either increasing the burden statement, } \\
\text { reducing the number of questions, or rewording questions so } \\
\text { that they capture data more readily available in business } \\
\text { records. }\end{array}$ & $\mathrm{Y}$ & $\begin{array}{l}\text { Burden increased from } 30 \text { minutes for } \\
\text { MOPS } 2010 \text { to } 45 \text { minutes for MOPS } 2015\end{array}$ \\
\hline
\end{tabular}


US Census Bureau

Cognitive Testing - MOPS 2015

\begin{tabular}{|c|c|c|c|}
\hline $\begin{array}{l}\text { Question } \\
\text { Number }\end{array}$ & Recommendation & Accepted? & Notes \\
\hline & & & $\begin{array}{l}\text { An earlier version of the survey included a } \\
\text { question asking respondents to forecast } \\
\text { GDP growth for } 2017 \text {. This question was } \\
\text { dropped in response to the first round of } \\
\text { pre-testing. }\end{array}$ \\
\hline & & & $\begin{array}{l}\text { An earlier version of the survey included a } \\
\text { question asking respondents about the } \\
\text { change in labor hours associated with } \\
\text { design of new products or services, demand } \\
\text { forecasting, advertising, supply chain } \\
\text { management, and compensation. This } \\
\text { question was dropped in response to the } \\
\text { first round of pre-testing. }\end{array}$ \\
\hline & & & $\begin{array}{l}\text { The language pertaining to the various } \\
\text { categories to be forecasted in questions 30- } \\
37 \text { is taken directly from the Annual } \\
\text { Survey of Manufacturers. Earlier versions } \\
\text { of the survey did not use exactly the same } \\
\text { language. The change to match the ASM } \\
\text { was suggested in the first round of pre- } \\
\text { testing. }\end{array}$ \\
\hline
\end{tabular}

Note: Table was developed from the recommendations, notes, and resolutions in Pick and Brennan (2015a, b). 
Table 5. Recommendations from usability testing of the MOPS 2015 survey instrument

\begin{tabular}{|c|c|c|c|}
\hline $\begin{array}{l}\text { Question } \\
\text { Number }\end{array}$ & Recommendation & Accepted? & Notes \\
\hline $\begin{array}{l}\text { Login } \\
\text { Screen }\end{array}$ & $\begin{array}{l}\text { Provide a resource to respondents who lost their username } \\
\text { and password, whether by generating a new username and/or } \\
\text { password, or simply a link that tells respondents who to call } \\
\text { if they lost a password. }\end{array}$ & $\mathrm{Y}$ & Information is available on the FAQ. \\
\hline $\begin{array}{l}\text { Login } \\
\text { Screen }\end{array}$ & $\begin{array}{l}\text { Consider emphasizing the sentences discussing the } 50 \\
\text { minute time-out feature, perhaps by placing them in closer } \\
\text { proximity to the User ID and Password fields or by visually } \\
\text { emphasizing the text with a bold and/or red font. They could } \\
\text { also be repeated on subsequent screens. }\end{array}$ & $\mathrm{N}$ & \\
\hline $\begin{array}{l}\text { Login } \\
\text { Screen }\end{array}$ & $\begin{array}{l}\text { Census survey staff should be aware of the issue with saved } \\
\text { login information when fielding calls from respondents who } \\
\text { are having difficulty logging in. There should also be a } \\
\text { mention of this in the FAQ section. }\end{array}$ & $\mathrm{N}$ & \\
\hline Main Menu & $\begin{array}{l}\text { Allow respondents to modify their company name and/or } \\
\text { address information from the Main Menu, consistent with } \\
\text { other web surveys. }\end{array}$ & $\mathrm{Y}$ & \\
\hline \multicolumn{4}{|l|}{1} \\
\hline \multicolumn{4}{|l|}{2} \\
\hline 3 & $\begin{array}{l}\text { Allow respondents to select "Never/None" in addition to any } \\
\text { of the other answer choices. }\end{array}$ & $\mathrm{Y}$ & $\begin{array}{l}\text { MOPS } 2010 \text { did not allow for selection of } \\
\text { "Never/None" and other answer choices. }\end{array}$ \\
\hline 4 & See question 3 & & \\
\hline \multicolumn{4}{|l|}{5} \\
\hline \multicolumn{4}{|l|}{6} \\
\hline 7 & & & \\
\hline
\end{tabular}


US Census Bureau

Usability Testing - MOPS 2015

\begin{tabular}{|c|c|c|c|}
\hline $\begin{array}{l}\text { Question } \\
\text { Number }\end{array}$ & Recommendation & Accepted? & Notes \\
\hline 8 & $\begin{array}{l}\text { Consider providing a more exhaustive list of answer choices, } \\
\text { or an "other, specify" option. }\end{array}$ & $\mathrm{N}$ & Maintain consistency with MOPS 2010. \\
\hline 8 & $\begin{array}{l}\text { Consider adding the definition of manager to any items } \\
\text { where the term is used, or defining it in the help/FAQ } \\
\text { section. }\end{array}$ & $\mathrm{Y}$ & Definition added to FAQ. \\
\hline \multicolumn{4}{|c|}{ ( } \\
\hline 10 & $\begin{array}{l}\text { If the survey sponsors are interested in bonuses of any type, } \\
\text { and not specifically bonuses given for performance, consider } \\
\text { rewording the question to remove the performance clause. If } \\
\text { they are only interested in bonuses for performance, do not } \\
\text { change the question, but beware that respondents may not } \\
\text { answer appropriately }\end{array}$ & $\mathrm{N}$ & Maintain consistency with MOPS 2010. \\
\hline \multicolumn{4}{|l|}{11} \\
\hline \multicolumn{4}{|l|}{12} \\
\hline 13 & Consider adding a response choice for team performance. & $\mathrm{N}$ & Maintain consistency with MOPS 2010. \\
\hline 13 & $\begin{array}{l}\text { Consider another word for “non-manager," to help visually } \\
\text { distinguish between the questions on non-managers that } \\
\text { immediately follow questions on managers. }\end{array}$ & $\mathrm{N}$ & Maintain consistency with MOPS 2010. \\
\hline 14 & See question 13. & & \\
\hline 15 & $\begin{array}{l}\text { Consider another word for “non-manager," to help visually } \\
\text { distinguish between the questions on non-managers that } \\
\text { immediately follow questions on managers. }\end{array}$ & $\mathrm{N}$ & Maintain consistency with MOPS 2010. \\
\hline 16 & See question 15. & & \\
\hline
\end{tabular}


US Census Bureau

Usability Testing - MOPS 2015

\begin{tabular}{|c|c|c|c|}
\hline $\begin{array}{l}\text { Question } \\
\text { Number }\end{array}$ & Recommendation & Accepted? & Notes \\
\hline 17 & $\begin{array}{l}\text { Change the broad word "location" to the more specific } \\
\text { version "mailing address" (or something similar). } \\
\text { Alternatively, if the word "location" is kept, considering } \\
\text { adding the term to the FAQ document and provide a context- } \\
\text { specific definition of "location.” }\end{array}$ & $\mathrm{N}$ & $\begin{array}{l}\text { "Establishment" is defined in the FAQ as } \\
\text { "a single physical location where business } \\
\text { is conducted." "Location" is the standard } \\
\text { language for business surveys. }\end{array}$ \\
\hline \multicolumn{4}{|l|}{18} \\
\hline \multicolumn{4}{|l|}{19} \\
\hline \multicolumn{4}{|l|}{20} \\
\hline \multicolumn{4}{|l|}{21} \\
\hline \multicolumn{4}{|l|}{22} \\
\hline \multicolumn{4}{|l|}{23} \\
\hline \multicolumn{4}{|l|}{24} \\
\hline \multicolumn{4}{|l|}{25} \\
\hline \multicolumn{4}{|l|}{26} \\
\hline 27 & $\begin{array}{l}\text { Allow respondents to select "Never/None" in addition to any } \\
\text { of the other answer choices. }\end{array}$ & $\mathrm{Y}$ & $\begin{array}{l}\text { MOPS } 2010 \text { did not allow for selection of } \\
\text { "Never/None” and other answer choices. }\end{array}$ \\
\hline 27 & $\begin{array}{l}\text { To remain consistent with the rest of the survey, put the } \\
2010 \text { question first, followed by the } 2015 \text { question. }\end{array}$ & $\mathrm{Y}$ & $\begin{array}{l}\text { The order of these responses could not be } \\
\text { reversed on the paper forms due to time } \\
\text { constraints. }\end{array}$ \\
\hline 28 & See question 27 & & \\
\hline \multicolumn{4}{|l|}{29} \\
\hline $\begin{array}{l}\text { Uncertainty } \\
\text { Example }\end{array}$ & $\begin{array}{l}\text { It should be made clearer, via extra text, that the examples } \\
\text { on the example section are NOT boxes to be filled out. }\end{array}$ & $\mathrm{Y}$ & $\begin{array}{l}\text { A text box with a solid border was added to } \\
\text { the top of the screen. }\end{array}$ \\
\hline $\begin{array}{l}\text { Uncertainty } \\
\text { Example }\end{array}$ & Correct the spelling for the word "judgment." & $\mathrm{Y}$ & \\
\hline
\end{tabular}


US Census Bureau

Usability Testing - MOPS 2015

\begin{tabular}{|c|c|c|c|}
\hline $\begin{array}{l}\text { Question } \\
\text { Number }\end{array}$ & Recommendation & Accepted? & Notes \\
\hline $\begin{array}{l}\text { Uncertainty } \\
\text { Example }\end{array}$ & Insert “Report in $\$ 1000$ ” above the data entry box & $\mathrm{Y}$ & \\
\hline 30 & $\begin{array}{l}\text { Add an auto-sum feature to show respondents the sum of } \\
\text { their numbers as they enter them; alternatively, add a static } \\
\text { " } 100 \text { " at the bottom to emphasize that the total must equal } \\
100 .\end{array}$ & $\mathrm{Y}$ & Auto-sum feature was added. \\
\hline 30 & $\begin{array}{l}\text { Add instructions on how to interpret the variable of interest } \\
\text { to the FAQ document, as the examples listed do not seem to } \\
\text { clarify the term. }\end{array}$ & $\mathrm{Y}$ & $\begin{array}{l}\text { Definitions are identical to the definitions } \\
\text { used in the instructions for the } 2015 \text { ASM. }\end{array}$ \\
\hline 30 & Insert “Report in $\$ 1000 ”$ above the data entry box & $\mathrm{Y}$ & \\
\hline 31 & See question 30. & & \\
\hline 32 & See question 30. & & \\
\hline 33 & See question 30. & & \\
\hline 34 & $\begin{array}{l}\text { Add an auto-sum feature to show respondents the sum of } \\
\text { their numbers as they enter them; alternatively, add a static } \\
\text { " } 100 \text { " at the bottom to emphasize that the total must equal } \\
100 .\end{array}$ & $\mathrm{Y}$ & Auto-sum feature was added. \\
\hline 34 & $\begin{array}{l}\text { Add instructions on how to interpret the variable of interest } \\
\text { to the FAQ document, as the examples listed do not seem to } \\
\text { clarify the term. }\end{array}$ & $\mathrm{Y}$ & $\begin{array}{l}\text { Definitions are identical to the definitions } \\
\text { used in the instructions for the } 2015 \text { ASM. }\end{array}$ \\
\hline 35 & See question 34 . & & \\
\hline 36 & See question 30. & & \\
\hline 37 & See question 30. & & \\
\hline 38 & & & \\
\hline 39 & & & \\
\hline 40 & & & \\
\hline
\end{tabular}


US Census Bureau

Usability Testing - MOPS 2015

\begin{tabular}{|c|c|c|c|}
\hline $\begin{array}{l}\text { Question } \\
\text { Number }\end{array}$ & Recommendation & Accepted? & Notes \\
\hline \multicolumn{4}{|l|}{$\overline{411}$} \\
\hline 42 & $\begin{array}{l}\text { In the FAQ, address how to address cases where part-time } \\
\text { workers are members of a union from another job. }\end{array}$ & $\mathrm{N}$ & $\begin{array}{l}\text { FAQ was developed using definitions and } \\
\text { terminology that has been proven } \\
\text { successful for other Census products. This } \\
\text { issue could not be addressed using existing } \\
\text { Census language. }\end{array}$ \\
\hline \multicolumn{4}{|l|}{43} \\
\hline 44 & $\begin{array}{l}\text { Provide brief descriptions to the answer choices, and provide } \\
\text { an Other (specify) response option. Consider addressing this } \\
\text { in the FAQ document. }\end{array}$ & $\mathrm{N}$ & $\begin{array}{l}\text { FAQ was developed using definitions and } \\
\text { terminology that has been proven } \\
\text { successful for other Census products. This } \\
\text { issue could not be addressed using existing } \\
\text { Census language. }\end{array}$ \\
\hline \multicolumn{4}{|l|}{45} \\
\hline \multicolumn{4}{|l|}{46} \\
\hline 47 & $\begin{array}{l}\text { Move this question to the beginning of the survey, so } \\
\text { respondents are aware that they are responsible for choosing } \\
\text { the timeframe that will be used throughout the questionnaire, } \\
\text { and that they should be aware of it and apply it consistently } \\
\text { throughout. }\end{array}$ & $\mathrm{N}$ & $\begin{array}{l}\text { This certification is standard on Census } \\
\text { forms. }\end{array}$ \\
\hline 47 & Remove this question from the survey. & $\mathrm{N}$ & $\begin{array}{l}\text { This certification is standard on Census } \\
\text { forms. }\end{array}$ \\
\hline $\begin{array}{l}\text { Review } \\
\text { Screen }\end{array}$ & $\begin{array}{l}\text { Use a review screen template borrowed from other web } \\
\text { surveys, such as the Annual Survey of Entrepreneurs, to } \\
\text { more easily identify problematic items. }\end{array}$ & $\mathrm{N}$ & $\begin{array}{l}\text { Not possible given time and technology } \\
\text { constraints. }\end{array}$ \\
\hline $\begin{array}{l}\text { General } \\
\text { Remarks }\end{array}$ & Consider making the PDF survey fillable. & $\mathrm{N}$ & $\begin{array}{l}\text { Not possible given time and technology } \\
\text { constraints. }\end{array}$ \\
\hline
\end{tabular}


US Census Bureau

Usability Testing - MOPS 2015

\begin{tabular}{|c|c|c|c|}
\hline $\begin{array}{l}\text { Question } \\
\text { Number }\end{array}$ & Recommendation & Accepted? & Notes \\
\hline & $\begin{array}{l}\text { Add a screener question asking respondents when their } \\
\text { establishment opened and do not ask recall questions if the } \\
\text { answer is after } 2010 \text {. }\end{array}$ & $\mathrm{N}$ & $\begin{array}{l}\text { Maintain consistency with MOPS } 2010 \text { as } \\
\text { well as the paper form. }\end{array}$ \\
\hline & $\begin{array}{l}\text { Provide easy and transparent access to } 2010 \text { survey } \\
\text { submissions to respondents who completed the } 2010 \text { MOPS. }\end{array}$ & $\mathrm{N}$ & $\begin{array}{l}\text { Every effort will be made to provide this } \\
\text { data to respondents, but because MOPS } \\
2010 \text { was not processed through the usual } \\
\text { Census system, this may not be possible. }\end{array}$ \\
\hline & $\begin{array}{l}\text { The FAQ section should be more exhaustive, and address } \\
\text { any concerns that came up frequently during testing. }\end{array}$ & $\mathrm{N}$ & $\begin{array}{l}\text { The FAQ was limited to questions and } \\
\text { answers that are in use for other Census } \\
\text { surveys. }\end{array}$ \\
\hline & Change the tab for FAQ to "FAQ/Help." & $\mathrm{N}$ & \\
\hline & $\begin{array}{l}\text { Review all questions that allow only one answer selection, } \\
\text { and consider if it is possible that more than one option could } \\
\text { be selected. }\end{array}$ & $\mathrm{N}$ & Maintain consistency with MOPS 2010. \\
\hline & $\begin{array}{l}\text { Change "Next" button to "Save and Continue" to inform } \\
\text { respondents that the survey is saving their answers each time } \\
\text { they proceed to the next question. }\end{array}$ & $\mathrm{Y}$ & \\
\hline & $\begin{array}{l}\text { Make text of error messages more specific and identify the } \\
\text { specific location of the problem with an asterisk or } \\
\text { highlighting. }\end{array}$ & $\mathrm{N}$ & $\begin{array}{l}\text { Not possible given time and technology } \\
\text { constraints. }\end{array}$ \\
\hline & $\begin{array}{l}\text { Rather than suggest that respondents "ignore" the warning, } \\
\text { consider changing the warning to read "to continue to the } \\
\text { next question and address this issue later, press the Next } \\
\text { button again.” }\end{array}$ & $\mathrm{N}$ & $\begin{array}{l}\text { Maintain standard Census web form } \\
\text { language. }\end{array}$ \\
\hline
\end{tabular}


US Census Bureau

Usability Testing - MOPS 2015

\begin{tabular}{|c|c|c|c|}
\hline $\begin{array}{l}\text { Question } \\
\text { Number }\end{array}$ & Recommendation & Accepted? & Notes \\
\hline & $\begin{array}{l}\text { To emphasize the instruction that tells respondents they can } \\
\text { proceed to the next question without addressing the error, } \\
\text { separate it spatially from the previous sentence. }\end{array}$ & $\mathrm{Y}$ & \\
\hline & $\begin{array}{l}\text { To emphasize a change in the theme of questions as a } \\
\text { respondent enters a new section, the survey could have a } \\
\text { page serve as a "bumper," showing only the section name } \\
\text { and telling respondents to proceed. }\end{array}$ & $\mathrm{N}$ & $\begin{array}{l}\text { Maintain consistency with paper } \\
\text { instrument and MOPS } 2010 .\end{array}$ \\
\hline & $\begin{array}{l}\text { Add the drop-down box with a list of the screens that would } \\
\text { allow respondents to navigate directly to any screen. }\end{array}$ & $\mathrm{N}$ & $\begin{array}{l}\text { Not possible given time and technology } \\
\text { constraints. }\end{array}$ \\
\hline & $\begin{array}{l}\text { Ensure that respondents will be provided with a PDF that } \\
\text { shows their completed questionnaire. }\end{array}$ & $\mathrm{Y}$ & \\
\hline & $\begin{array}{l}\text { Ensure that respondents who use Google Chrome to } \\
\text { complete the survey are able to see their completed answers. }\end{array}$ & $\mathrm{N}$ & $\begin{array}{l}\text { Google Chrome is not supported by the } \\
\text { U.S. Census Bureau. }\end{array}$ \\
\hline & $\begin{array}{l}\text { Ensure that the introductory letter tells respondents the } \\
\text { benefits of participating in the survey and the purposes of } \\
\text { collecting the data. }\end{array}$ & $\mathrm{Y}$ & \\
\hline & $\begin{array}{l}\text { Removing the } 2010 \text { questions and removing the Uncertainty } \\
\text { questions, both mentioned in other recommendations, would } \\
\text { go a long way towards reducing the overall survey burden. }\end{array}$ & $\mathrm{N}$ & $\begin{array}{l}\text { Recall questions and Uncertainty questions } \\
\text { are both integral to the MOPS instrument. }\end{array}$ \\
\hline & $\begin{array}{l}\text { Consider using a bold font for emphasis, rather than } \\
\text { capitalization. }\end{array}$ & $\mathrm{N}$ & $\begin{array}{l}\text { Bold fonts are generally used for question } \\
\text { text. }\end{array}$ \\
\hline & $\begin{array}{l}\text { Explore the possibility of providing respondents with } \\
\text { benchmarking data after they submit the survey; if this is not } \\
\text { feasible to be provided to them immediately after they } \\
\text { complete the survey, consider reaching out to respondents } \\
\text { upon publication of the data to make them aware of the } \\
\text { publication. }\end{array}$ & $\mathrm{Y}$ & $\begin{array}{l}\text { Creation of a benchmarking tool is a goal } \\
\text { of the Census Bureau and research } \\
\text { partners. }\end{array}$ \\
\hline
\end{tabular}


US Census Bureau

Usability Testing - MOPS 2015

\begin{tabular}{|l|l|l|l|}
\hline $\begin{array}{l}\text { Question } \\
\text { Number }\end{array}$ & Recommendation & Accepted? & Notes \\
\hline \hline & $\begin{array}{l}\text { Add the phrase “estimates are acceptable” to any question } \\
\text { asking for numbers to be reported. }\end{array}$ & $\begin{array}{l}\text { Maintain consistency with paper } \\
\text { instrument. Instruction letter indicates that } \\
\text { estimates are acceptable throughout the } \\
\text { survey. }\end{array}$ \\
\hline & $\begin{array}{l}\text { Change the title of Section D from “Uncertainty” to } \\
\text { "Forecasting.” }\end{array}$ & $\mathrm{N}$ & $\begin{array}{l}\text { Maintain consistency with paper } \\
\text { instrument. }\end{array}$ \\
\hline & $\begin{array}{l}\text { Generate warning if scenarios are not in ascending order for } \\
\text { questions 31, 33, 35, and 37 }\end{array}$ & $\mathrm{Y}$ & \\
\hline
\end{tabular}

Note: Table was developed from the recommendations, notes, and resolutions in Herrell and Mesner (2016) 